\title{
Genes regulating hormone stimulus and response to protein signaling revealed differential expression pattern during porcine oocyte in vitro maturation, confirmed by lipid concentration
}

\author{
Błażej Chermuła ${ }^{1}$ Michal Jeseta ${ }^{2} \cdot$ Patrycja Sujka-Kordowska $^{3}$ - Aneta Konwerska ${ }^{3} \cdot$ Maurycy Jankowski $^{4}$. \\ Wiesława Kranc ${ }^{4}$. levgeniia Kocherova ${ }^{4}$. Piotr Celichowski ${ }^{3}$. Paweł Antosik ${ }^{5}$. Dorota Bukowska ${ }^{6}$. \\ Irena Milakovic ${ }^{7}$ - Marie Machatkova ${ }^{7}$. Leszek Pawelczyk ${ }^{1} \cdot$ Dariusz lżycki $^{8} \cdot$ Maciej Zabel $^{9,10} \cdot$ Paul Mozdziak $^{11}$. \\ Bartosz Kempisty ${ }^{2,3,4,5} \cdot$ Hanna Piotrowska-Kempisty ${ }^{12}$
}

Accepted: 6 March 2020 / Published online: 18 March 2020

(c) The Author(s) 2020

\begin{abstract}
Genes influencing oocyte maturation may be valuable for predicting their developmental potential, as well as discerning the mechanistic pathways regulating oocyte development. In the presented research microarray gene expression analysis of immature and in vitro matured porcine oocytes was performed. Two groups of oocytes were compared in the study: before $(3 \times n=50)$ and after in vitro maturation $(3 \times n=50)$. The selection of viable oocytes was performed using the brilliant cresyl blue (BCB) test. Furthermore, microarrays and RT-qPCR was used to analyze the transcriptome of the oocytes before and after IVM. The study focused on the genes undergoing differential expression in two gene-ontology groups: "Cellular response to hormone stimulus" and "Cellular response to unfolded protein", which contain genes that may directly or indirectly be involved in signal transduction during oocyte maturation. Examination of all the genes of interest showed a lower level of their expression after IVM. From the total number of genes in these gene ontologies ten of the highest change in expression were identified: FOS, ID2, BTG2, CYR61, ESR1, AR, TACR3, CCND2, EGR2 and TGFBR3. The successful maturation of the oocytes was additionally confirmed with the use of lipid droplet assay. The genes were briefly described and related to the literature sources, to investigate their potential roles in the process of oocyte maturation. The results of the study may serve as a basic molecular reference for further research aimed at improving the methods of oocyte in vitro maturation, which plays an important role in the procedures of assisted reproduction.
\end{abstract}

Keywords Pig $\cdot$ Oocyte maturation $\cdot$ Microarray $\cdot$ Mitochondrial activity

Bartosz Kempisty

bkempisty@ump.edu.pl

1 Division of Infertility and Reproductive Endocrinology, Department of Gynecology, Obstetrics and Gynecological Oncology, Poznan University of Medical Sciences, Poznan, Poland

2 Department of Obstetrics and Gynecology, University Hospital and Masaryk University, Brno, Czech Republic

3 Department of Histology and Embryology, Poznan University of Medical Sciences, 6 Święcickiego St., 60-781 Poznan, Poland

4 Department of Anatomy, Poznan University of Medical Sciences, Poznan, Poland

5 Department of Veterinary Surgery, Nicolaus Copernicus University in Torun, Toruń, Poland
6 Department of Elementary and Preclinical Sciences, Nicolaus Copernicus University in Torun, Toruń, Poland

7 Veterinary Research Institute, Brno, Czech Republic

8 Chair of Biotechnology, Department of Cancer Immunology, Poznan University of Medical Sciences, Poznan, Poland

9 Department of Histology and Embryology, Wroclaw Medical University, Wrocław, Poland

10 Division of Anatomy and Histology, University of Zielona Gora, Zielona Gora, Poland

11 Physiology Graduate Program, North Carolina State University, Raleigh, NC, USA

12 Department of Toxicology, Poznan University of Medical Sciences, Poznan, Poland 


\section{Introduction}

Determination and characterization of the expression of genes which regulate the hormone stimulus and response to protein signaling in mature oocytes is valuable for predicting their developmental potential. It has been already proven that evolutional capacity of oocytes is acquired in the long stages of folliculogenesis (Rienzi et al. 2011; Rybska et al. 2018a). In this process, the main role is played by the bi-directional communication between the oocyte and cumulus cells (CCs) (Celichowski et al. 2018). Corona radiata cells, directly contacting the oocyte, supply it with molecular regulating factors and necessary nutrients. The main goal of all these complex development processes is ensuring the nuclear and cytoplasmic cellular maturity of the oocyte (Kahraman et al. 2018), which is achieved through gap junctions between the cells of the cumulus-oocyte complexes (COCs). Results of previous research illustrated that the cooperation of somatic cells surrounding the oocyte is important for the functioning of the signaling and metabolic pathways that enable the oocyte to reach metaphase II (Chamier-Gliszczyńska et al. 2018).

The proper development of ovaries and ovarian follicles requires appropriate gene expression. During oocyte maturation, many genes, such as the TGF- $\beta$ receptorassociated genes, are involved in the activation of signaling pathways. TGF- $\beta$ s are cytokines from the family of intercellular signaling factors that are mainly responsible for regulating proliferation, differentiation and embryonic development (Mauviel 2005). TGF- $\beta$ receptor is the main cellular receptor responsible for morphogenesis and oocyte maturation. Firstly, the ligand binds to the TGF$\beta$ receptor on the cell surface, which initiates a series of molecular signals, inducing serine-threonine kinase activity.

The meiosis of human oocytes begins during embryonic development and stops in late prophase. When women reach sexual maturity, the appearance of a luteinizing hormone $(\mathrm{LH})$ wave directly affects the granulosa cells, which surround and are in bi-directional communication with the oocyte, releasing the ovum from its arrested state and preparing it for further fertilization (Kranc et al. 2018; Rybska et al. 2018b). The inhibition of preovulatory vesicle meiotic progression is dependent, inter alia, on the cyclic guanosine monophosphate nucleotide (cGMP) and series of proteins that diffuse from the granulosa cells through the gap junctions. Recent works suggest that LH surge generates protein signals that are transferred to the oocyte in the same way as cGMP (Shuhaibar et al. 2015). Taking the above into account, it seems interesting to examine the impact of the expression of oocyte genes involved in the signaling associated with the meiosis resumption process.

Identifying and characterizing genes regulating hormone stimulus and response to protein signaling may prove to be important for assessing their expression during immature oocyte at prophase I stage maturation in the assisted reproduction techniques (ART). Thanks to oocyte in vitro maturation (IVM) application in humans ART procedures, the use of controlled hyper-stimulation could be eliminated. It would undoubtedly have a positive clinical effect in patients suffering from PCOS (polycystic ovary syndrome). PCOS patients are highly sensitive to gonadotropin stimulation, and it may consequently lead to the appearance of ovarian hyperstimulation syndrome (OHSS) (Vuong et al. 2020). Thus, a thorough understanding of the processes regulating porcine oocyte maturation in in vitro conditions can contribute to increasing the effectiveness of ART techniques in animals breeding as well as in assisted reproduction techniques used in humans.

Implementation of the microarray expression method for routine genetic diagnosis enabled the identification of new cell functions involved in the development of the ovarian follicle (Dias et al. 2018; Kranc et al. 2018; Nawrocki et al. 2018) and is a helpful tool for gene transcript analysis in cells and tissues (Celichowski et al. 2018; Chamier-Gliszczyńska et al. 2018; Chronowska 2014). The objective of the study was to evaluate the expression of genes expressed in porcine oocytes to define genes undergoing differential expression in two analyzed ontology groups: "Cellular response to hormone stimulus" and "Cellular response to unfolded protein", using microarray gene expression analysis of immature and in vitro matured porcine oocytes. The resulting analysis of gene of interest expression patterns may provide us with new insight into the mechanisms of oocyte growth and maturation in in vitro culture.

\section{Materials and methods}

Large portions of the Materials and Methods section were based on other works from the same cycle of studies, employing similar experimental procedures (Budna et al. 2017; Celichowski et al. 2018).

\section{Experimental design}

Porcine oocytes were either classified as (1) BCB positive $(+)$ for molecular analysis or (2) BCB positive (+) oocytes that were matured in vitro (IVM). 


\section{Animals}

A total of 45 Landrace gilts, with an average age of 155 days (range 140-170 days) and an average weight was $100 \mathrm{~kg}$ $(95-120 \mathrm{~kg})$ were maintained under identical and standard management practices. All experiments were approved by the Poznan University of Medical Sciences Bioethical Committee (Resolution No. 32/2012, approved on 1/6/2012).

\section{Porcine ovaries and cumulus-oocyte complexes (COCs)}

Ovaries and reproductive pathways were recovered during slaughter and transported to the laboratory within $40 \mathrm{~min}$, at $37{ }^{\circ} \mathrm{C}$ in $0.9 \% \mathrm{NaCl}$. Subsequently, ovaries were placed in a $5 \%$ fetal bovine serum solution (FBS, Sigma-Aldrich Co., St. Louis, MO) dissolved in PBS. Single large follicles ( $>5 \mathrm{~mm}$ ) were then punctured using a $5 \mathrm{ml}$ syringe with a 20G needle in a sterile Petri dish to recover the COCs, which were placed in a Petri dish, COCs washed three times with PBS supplemented with $50 \mu \mathrm{g} / \mathrm{ml}$, gentamycin $36 \mu \mathrm{g} / \mathrm{ml}$ of pyruvate and $0.5 \mathrm{mg} / \mathrm{ml}$ bovine serum albumin (BSA; Sigma-Aldrich, St. Louis, MO, USA). COCs were selected under an inverted microscope (Zeiss, Axiovert 35, Lübeck, Germany), counted and morphologically evaluated using the system presented by Jackowska et al. (2009). COCs of Grade I, characterized by homogeneous ooplasm and compact CCs, were the only ones considered in subsequent stages of the experiment. 300 first degree oocytes ( $3 \times n=50$ immature groups, $3 \times n=50$ IVM groups) were collected.

\section{Hematoxylin and eosin ovaries staining}

Ovaries collected from 5 porcine specimen were mixed in Bouin's solution for $48 \mathrm{~h}$, dehydrated, cleared and embedded in paraffin. Sections of ovaries $(3-4 \mu \mathrm{m})$ were cut using a semi-automatic rotary microtome (Leica RM 2145, Leica Microsystems, Nussloch, Germany) and stained employing a routine hematoxylin and eosin ( $\mathrm{H}$ and $\mathrm{E})$ procedure. Histological sections were evaluated using a light microscope, with selected pictures taken with a high-resolution scanning technique and Olympus BX61VS microscope scanner (Olympus, Tokyo, Japan).

\section{Selection of oocytes by BCB staining}

The BCB staining assay was performed to select oocytes for subsequent tests (Kempisty et al. 2011). This test bases on the activity of the glucose-6-phosphate, described to be lower in growth oocytes and higher in those undergoing development. This enzyme has the ability to convert the $\mathrm{BCB}$ staining from blue to colorless, hence serving as a good indicator of oocyte's maturational competence, with $\mathrm{BCB}+$ oocytes proven to be larger and more competent for maturation (Wu et al. 2007). Oocytes were rinsed twice with modified Dulbecco PBS (DPBS) (Sigma-Aldrich, St. Louis, MO, USA) supplemented with $50 \mu \mathrm{g} / \mathrm{ml}$ streptomycin, $50 \mathrm{IU} / \mathrm{ml}$ penicillin (Sigma-Aldrich, St. Louis, MO, USA), 0, 4\% BSA [w/v], $0.34 \mathrm{mM}$ pyruvate and $5.5 \mathrm{mM}$ glucose (DPBSm). The oocytes were treated with $13 \mu$ M BCB (Sigma-Aldrich, St. Louis, MO, USA) diluted in DPBSm at $38.5{ }^{\circ} \mathrm{C}$ and $5 \%$ CO 2 for 90 min. Oocytes were transferred to DPBSm and washed twice. During the washing procedure, the oocytes were examined under an inverted microscope and classified as either blue $(\mathrm{BCB}+)$ or colorless (BCB-). Only BCB+oocytes were used for subsequent molecular analysis (immature group) or IVM,

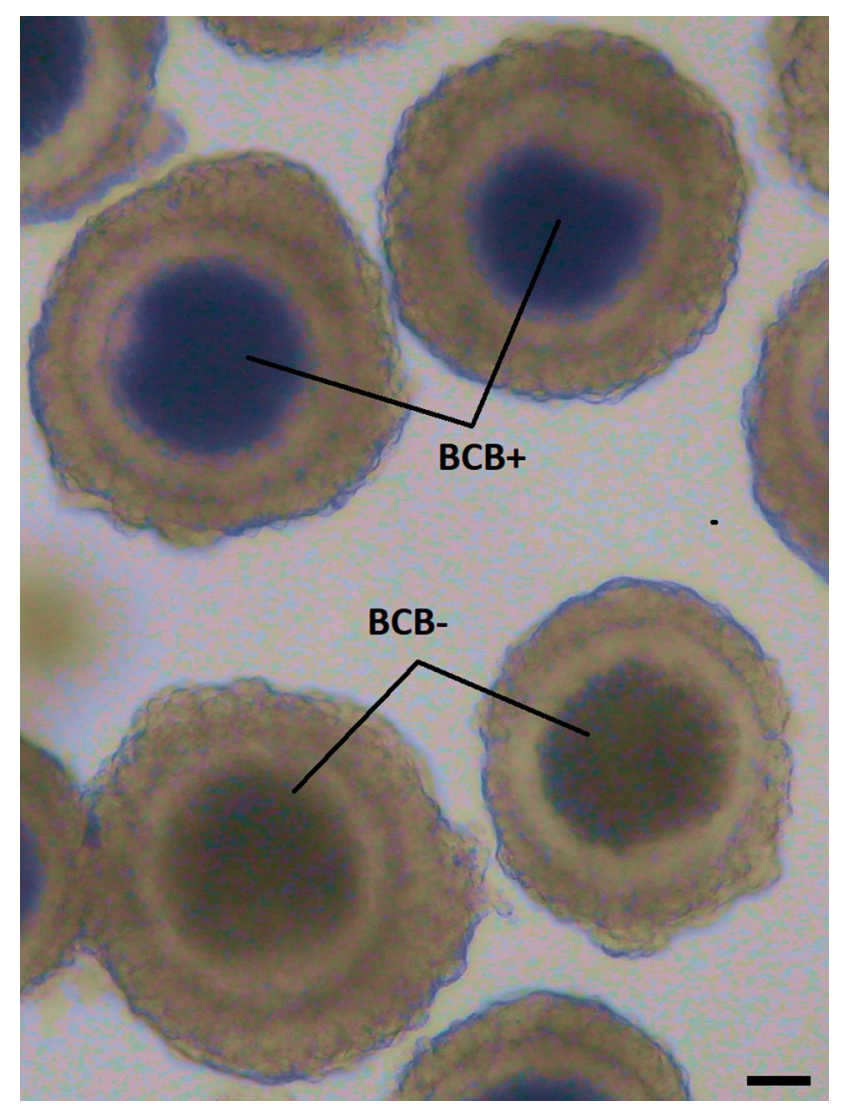

Fig. 1 Briliant cresyl blue (BCB) staining of porcine oocytes. Representative picture of $\mathrm{BCB}+$ and $\mathrm{BCB}-$ oocytes after their staining by $\mathrm{BCB}$. During the washing procedure, oocytes were examined under an inverted microscope and classified as blue (BCB+) or colorless (BCB-). Only $\mathrm{BCB}+$ oocytes were used for subsequent molecular analysis (immature group) or IVM. The contrast of the Figure was globally adjusted to better visualize the difference between blue and colorless oocytes 
followed by a second $\mathrm{BCB}$ test and molecular analysis (IVM group). An example of the $\mathrm{BCB}$ staining assay, showing samples of both $\mathrm{BCB}+$ and $\mathrm{BCB}-$ oocytes can be found on Fig. 1.

\section{Denudation of porcine oocytes}

Immature oocytes have dense layers of cumulus cells. Thus, COCs were first incubated with bovine testicular hyaluronidase (Sigma-Aldrich, St. Louis, MO, USA) for 2 min at $38{ }^{\circ} \mathrm{C}$ to separate cumulus and granulosa cells. The cells were then removed by vortexing in $1 \%$ sodium citrate buffer, followed by mechanical displacement by means of a small diameter glass micropipette. Both in the case of the immature oocytes purification and those after in vitro maturation process, denudation was carried out until corona radiata cells were completely removed from oocyte zona pellucida.

\section{Culture of cumuls-oocyte complexes}

COCs were cultured in 4-well Nunclon ${ }^{\mathrm{TM}}$ plates in $500 \mu \mathrm{l}$ of standard IVM porcine culture medium TCM-199 (tissue culture medium) with Earle salts and L-glutamine (Gibco BRL Life Technologies, Grand Island, NY, USA), supplemented with $0.1 \mathrm{mg} / \mathrm{ml}$ sodium pyruvate (SigmaAldrich, St. Louis, MO, USA), $2.2 \mathrm{mg} / \mathrm{ml}$ sodium bicarbonate (Nacalai Tesque, Inc., Kyoto, Japan) $10 \mathrm{mg} / \mathrm{ml}$ BSA, (SigmaAldrich, St. Louis, MO, USA), $0.1 \mathrm{mg} / \mathrm{ml}$ cysteine (Sigma-Aldrich, St. Louis, MO, USA), $10 \%$ filtered porcine follicular fluid (v/v) and gonadotropin supplements at final concentrations of $2.5 \mathrm{IU} / \mathrm{ml}$ of eCG (Intervet, Whitby, ON, Canada) and $2.5 \mathrm{IU} / \mathrm{ml}$ of hCG (Ayerst Laboratories, Inc., Philadelphia, PA, USA). All wells were flooded with a layer of mineral oil and maintained for $44 \mathrm{~h}$ at $38{ }^{\circ} \mathrm{C}$ in a $5 \% \mathrm{CO}_{2}$ atmosphere. After maturation, for the maturity assessment the $\mathrm{BCB}$ staining test was repeated, with only $\mathrm{BCB}+$ oocytes used for further study.

\section{RNA isolation}

Oocytes were analyzed before $(3 \mathrm{xn}=50)$ and after in vitro maturation $(3 \mathrm{xn}=50)$. Each group was combined into three independent samples representing separate experimental groups. Total RNA was extracted from the samples with RNeasy MinElute Kit Cleanup (Qiagen, Hilden, Germany) and TRI Reagent ${ }^{\circledR}$ (Sigma, St Louis, MO, USA), according to the manufacturer protocols and literature data (Chomczynski and Sacchi 1987). Total mRNA was measured using the optical density at $260 \mathrm{~nm}$, and the purity of RNA from the absorption ratio 260/280 $\mathrm{nm}$ (above 1.8) (NanoDrop spectrophotometer, Thermo Scientific, ALAB, Poland). The
RNA integrity was determined with the use of Bioanalyzer 2100 (Agilent Technologies, Inc., Santa Clara, CA, USA). Obtained RNA integrity (RIN) was ranging from 8.5 to 10 with an average of 9.2 (Agilent Technologies, Inc., Santa Clara, CA, USA). Each sample was separated and secured for further analysis. $100 \mathrm{ng}$ of the obtained RNA was used for microarray assays. The remaining RNA was used for the RT-qPCR analysis.

\section{Microarray expression analysis and statistics}

The Affymetrix procedure was described and used in our previous works regarding porcine oviductal cells (Kranc et al. 2018; Stefańska et al. 2018) and porcine oocytes (Borys-Wójcik et al. 2018; Budna et al. 2018). All experiments were carried out in triplicate. Total RNA (100 ng) from each sample was subjected to two rounds of sense cDNA amplification (Ambion ${ }^{\circledR}$ WT Expression Kit). cDNA was used for biotin marking and fragmentation by labeling and hybridization to the Affymetrix GeneChip ${ }^{\circledR}$ WT (Affymetrix, Santa Clara, CA, USA). Biotin-labeled cDNA fragments $(5.5 \mu \mathrm{g})$ were hybridized to the Affymetrix ${ }^{\circledR}$ Porcine Gene 1.1 ST Array Strip $\left(48^{\circ} \mathrm{C} / 20 \mathrm{~h}\right)$. The microarrays were then washed and stained according to the technical protocol presented by Affymetrix GeneAtlas Fluidics Station. The array strips were scanned using the GeneAtlas system imaging station. The initial analysis of the scanned chips was carried out using the Affymetrix GeneAtlas ${ }^{\mathrm{TM}}$ operational software. The quality of gene expression data was checked in accordance with the quality control criteria provided by the software.

All analyses were carried out using the BioConductor software, accordingly to the statistical $\mathrm{R}$ programming language. Robust Multiarray Averaging (RMA) algorithm implemented in the "affy" BioConductor package was used for normalization and summation of raw data and background correction. The biological annotation was taken from the BioConductor "oligo" package, in which the object, data frame and commentary were combined with a normalized data set, which led to the full gene data table. Statistical significance of the analyzed genes was carried out with the use of moderated t-statistics from the empirical Bayes' method. Obtained p-value was corrected for multiple comparisons using the Benjamini and Hochberg false discovery index. The choice of significantly altered gene expression was based on a p-value less than 0.05 and a greater fold expression change than $|2|$.

Functional grouping of gene annotations was performed using DAVID (Database for Annotation, Visualization and Integrated Discovery). Gene symbols for up- and down-regulated genes from each compared group were transferred into DAVID with the use of BioConductor 
"RDAVIDWebService" package. For further analysis, we chose extended GO terms, which had at least 5 genes and a $p$ value (Benjamini) lower than 0.05 . Improved GO conditions were subjected to a hierarchical clustering algorithm and were presented as heat maps.

The relationship between genes belonging to selected GO terms were analyzed with the GOplot package. The GO Plot package calculated the z-score: number of up-regulated genes minus the number of down-regulated genes divided by the square root of the number. This information allowed us to estimate the course of change of each gene ontology term.

Interactions between genes with different expression/ proteins belonging to the selected ontological groups were tested by using STRING10 software (Search Tool for the Retrieval of Interacting Genes). The list of gene names was used as a query to predict interactions. Search criteria based on the coexistence of genes/proteins in scientific texts (text exploration), co-expression and experimentally observed interactions. That analysis generated a gene/protein interaction network in which the intensity edge reflects the strength of the interaction results. In addition to predicting interaction, STRING also allowed us to perform functional enrichment of GO terms based on previously detected gene sets.

Functional interaction between the genes belonging to selected GO BP terms was analyzed by the REACTOME FIViz application for the Cytoscape 3.6.0 software. The ReactomeFIViz aims to find paths and patterns of networks related to cancer and other types of diseases. This application allows finding the paths stored in the Reactome database, enabling route enrichment analysis for the gene set, visualization of hit paths using manually arranged path diagrams directly in Cytoscape and testing functional compounds between genes in the pathways of interest. The application can also access the Reactome Functional Interaction (FI) network, which spans over $60 \%$ of human proteins with high reliability.

\section{Quantitative analysis of polymerase chain reaction in real time (RT-qPCR) analysis}

For RT-qPCR, total RNA isolated earlier from oocytes groups before and/or after IVM was used. RNA samples were resuspended in $20 \mu \mathrm{l}$ of RNase-free water and stored in a $-80{ }^{\circ} \mathrm{C}$ freezer. RNA samples were treated with DNase I and reverse transcribed (RT) into cDNA. RT-qPCR was performed in a real-time Light Cycler PCR detection system (Roche Diagnostics GmbH, Mannheim, Germany) using SYBRR Green I as a detection dye, with target cDNA quantified using a relative quantification method. The relative abundance of analyzed transcripts in each sample was
Table 1 Sequences of primers used for the RT-qPCR analysis

\begin{tabular}{|c|c|c|c|}
\hline Gene & Gene ID & Primer sequence $\left(5^{\prime}-3^{\prime}\right)$ & $\begin{array}{l}\text { Product } \\
\text { size } \\
\text { (bp) }\end{array}$ \\
\hline$A R$ & 397582 & $\begin{array}{l}\text { GGCAAAAGCAACGAAGAG } \\
\text { AC } \\
\text { CGACTCGGATAGGCTGCT } \\
\text { AC }\end{array}$ & 188 \\
\hline$B T G 2$ & 100048932 & $\begin{array}{l}\text { AACTCTCССТGСТССТСТСС } \\
\text { TGAGGATCCAGCCATAGTCC }\end{array}$ & 203 \\
\hline$C C N D 2$ & 397162 & $\begin{array}{l}\text { CGTCCAAGCTCAAAGAGA } \\
\text { CC } \\
\text { CGAAGAATGTGCTCGATG } \\
\text { AA }\end{array}$ & 169 \\
\hline CYR61 & 100153791 & $\begin{array}{l}\text { CTAGATGCTGCTCGGGTTTC } \\
\text { AGCTCCAAAATGAAGCAG } \\
\text { GA }\end{array}$ & 246 \\
\hline EGRl & 100520726 & $\begin{array}{l}\text { AGGTCACCATGGAAGGTC } \\
\text { TG } \\
\text { TCCAAAATCCATGCAAAT } \\
\text { CA }\end{array}$ & 152 \\
\hline$E G R 2$ & 100038004 & $\begin{array}{l}\text { ACCCAGAAGGCATCATCA } \\
\text { AC } \\
\text { GAGGGGTCCTGGTAGAGG } \\
\text { TC }\end{array}$ & 232 \\
\hline$E I F 2 A K 3$ & 100513348 & $\begin{array}{l}\text { CTCCAGGACAGCTGCCTT } \\
\text { AC } \\
\text { CATTCTGGGCTCTTCTTTGC }\end{array}$ & 192 \\
\hline ESR1 & 397435 & $\begin{array}{l}\text { AGCACCCTGAAGTCTCTG } \\
\text { GA } \\
\text { TGTGCCTGAAGTGAGACA } \\
\text { GG }\end{array}$ & 160 \\
\hline FOS & 100144486 & $\begin{array}{l}\text { TCGGTAAGCGTCTGAGAG } \\
\text { GT } \\
\text { AAAGCTCTTGCCATGCAGTT }\end{array}$ & 209 \\
\hline HSPA4 & 100524853 & $\begin{array}{l}\text { CAGGATTTGCCCTATCCAGA } \\
\text { CGGTTCCTCATTTTCCTCAA }\end{array}$ & 180 \\
\hline ID1 & 100522839 & $\begin{array}{l}\text { ССТCTGTTTTCCCATCTGGA } \\
\text { ATGCCTCСССТTTCTCATCT }\end{array}$ & 211 \\
\hline ID2 & 654298 & $\begin{array}{l}\text { CCCAAGGAGGACAAGTCA } \\
\text { AA } \\
\text { TCCCCATGGTGGGAATAG } \\
\text { TA }\end{array}$ & 180 \\
\hline$I G F B P 7$ & 100302573 & $\begin{array}{l}\text { TGACACCCCCTAAGGACA } \\
\text { TC } \\
\text { CGTCTGAATGGCCAGGTTAT }\end{array}$ & 173 \\
\hline$I H H$ & 397174 & $\begin{array}{l}\text { CTCCACTGCCCTCTCAGAAC } \\
\text { AGCTCGCAGCTGTGTCAC } \\
\text { TA }\end{array}$ & 182 \\
\hline INSR & 396755 & $\begin{array}{l}\text { GTGCCCGACCATCTGTAAGT } \\
\text { CCTGCCTCCTTGAGTTCTTG }\end{array}$ & 245 \\
\hline KLF10 & 100153665 & $\begin{array}{l}\text { AGGTTGTGAACGGAGGTT } \\
\text { TG } \\
\text { TAGCTTCTTGGCCGACAGAT }\end{array}$ & 160 \\
\hline
\end{tabular}


Table 1 (continued)

\begin{tabular}{|c|c|c|c|}
\hline Gene & Gene ID & Primer sequence $\left(5^{\prime}-3^{\prime}\right)$ & $\begin{array}{l}\text { Product } \\
\text { size } \\
\text { (bp) }\end{array}$ \\
\hline MMP14 & 397471 & $\begin{array}{l}\text { TCCAGAACTACACCCCCA } \\
\text { AG } \\
\text { GCTGTCACCATGGAAACC } \\
\text { TT }\end{array}$ & 185 \\
\hline PHIP & 100155644 & $\begin{array}{l}\text { TAAAAGCTGCAGGCATGT } \\
\text { TG } \\
\text { CAGTTGGAACAAGTCGCT } \\
\text { CA }\end{array}$ & 167 \\
\hline PLD1 & 100519446 & $\begin{array}{l}\text { CCTCCGTAATGGATGGAA } \\
\text { AA } \\
\text { CGCTGTTGAAACCCATACCT }\end{array}$ & 161 \\
\hline SERPINHI & 396773 & $\begin{array}{l}\text { CGTGGGTGTCACTATGATGC } \\
\text { TTCCCCATCCAGATCTTCAG }\end{array}$ & 192 \\
\hline TACR3 & 100521983 & $\begin{array}{l}\text { TCATTTATGCGCTTCACAGC } \\
\text { GTCTGGGTTTCAAGGGAT } \\
\text { CA }\end{array}$ & 156 \\
\hline$T G F B R 3$ & 397512 & $\begin{array}{l}\text { TTTGTTTTAGCTGGGGGTTG } \\
\text { TGGCCACAGGGATTTTTA } \\
\text { AG }\end{array}$ & 177 \\
\hline TXNIP & 733688 & $\begin{array}{l}\text { TCGAAGTGATGGATCTAG } \\
\text { TGGA } \\
\text { TCACCTTCACAGAACCCT } \\
\text { TTT }\end{array}$ & 151 \\
\hline$U B E 2 B$ & 100513527 & $\begin{array}{l}\text { TGGCATCTCCACTATGAGCA } \\
\text { ACCTGCCTTGTTCAACCAAC }\end{array}$ & 164 \\
\hline$V C P$ & 397524 & $\begin{array}{l}\text { ACCCTCCAAGGGAGTGCT } \\
\text { AT } \\
\text { GGCAATTGAATCCAGCTC } \\
\text { AT }\end{array}$ & 223 \\
\hline
\end{tabular}

normalized to internal standards (PBGD, B-ACTIN, 18S rRNA). For amplification, $2 \mu 1$ of diluted cDNA was added to $18 \mu \mathrm{l}$ PCR QuantiTectR SYBRR Green PCR (Master Mix Qiagen GmbH, Hilden, Germany) and primers (Table 1). To provide negative control for subsequent PCR, one RNA sample from each preparation was analyzed without an RT reaction.

\section{Lipid droplet examination}

The procedure of this step was based on sources found in the available literature (Bradley et al. 2016). Oocytes in germinal vesicle stage and mature oocytes, with the stages confirmed with the use of fluorescence microscopy methods (Fig. 2), were denuded of cumulus cells manually by narrow glass pipette in IVM culture medium with $0.1 \%(\mathrm{w} / \mathrm{v})$ hyaluronidase (Sigma Aldrich). 10 oocytes from each group were fixed in $3.7 \%$ paraformaldehyde solution for $60 \mathrm{~min}$ at room temperature. Subsequently the oocytes were washed in PBS and permeabilized with $1 \%$ Triton X-100 for $1 \mathrm{~h}$. The lipid droplets were stained in PBS supplemented with $0.4 \%$ BSA and $1 \mu \mathrm{M}$ Nile red dye (Invitrogen, Carlsbad, CA, USA) at room temperature for $10 \mathrm{~min}$. The oocytes were washed three times in PBS, with a single equatorial slice of each oocyte mounted on slide, avoiding oocyte compression, using Vectashield medium (Vector Lab, Burlingame, CA) containing $1 \mu \mathrm{M}$ of DNA dye (TO-PRO-3, Invitrogen; Carlsbad, CA, USA) for either GV or MII stage control. The slides were stored below $0{ }^{\circ} \mathrm{C}$ until the oocyte examination.

The oocytes were examined using a laser scanning confocal microscope (Leica TCS SP2 AOBS; Leica, Heidelberg, Germany) equipped with Ar and HeNe lasers. The $488 \mathrm{~nm}$ excitation band and 570-667 nm detector were used for lipid droplets visualization and $633 \mathrm{~nm}$ excitation
Fig. 2 Sample images taken during fluorescence microscopy confirmation of oocyte maturity. a Immature oocyte after isolation at germinal vesicle stage $(\mathrm{GV})$, b mature oocyte after $44 \mathrm{~h}$ of cultivation at metaphase of second meiotic division (MII); $N$ nucleolus, $P B$ polar body, $\mathrm{CH}$ condensed chromosomes. Scale bar represents $30 \mu \mathrm{m}$
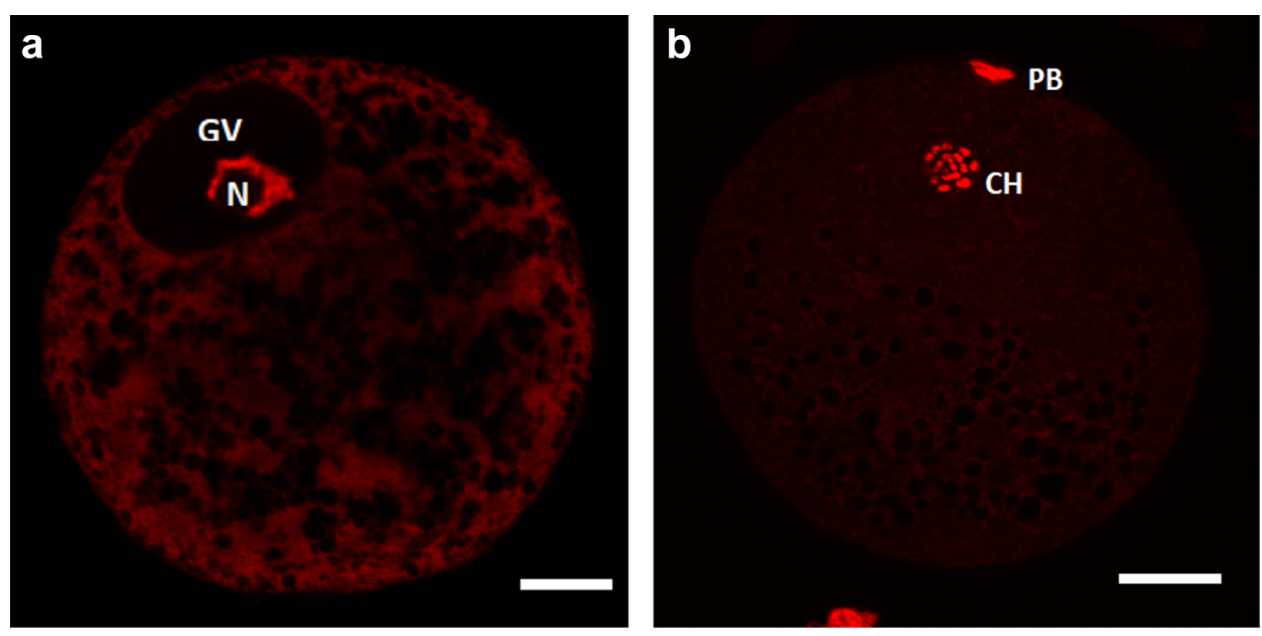

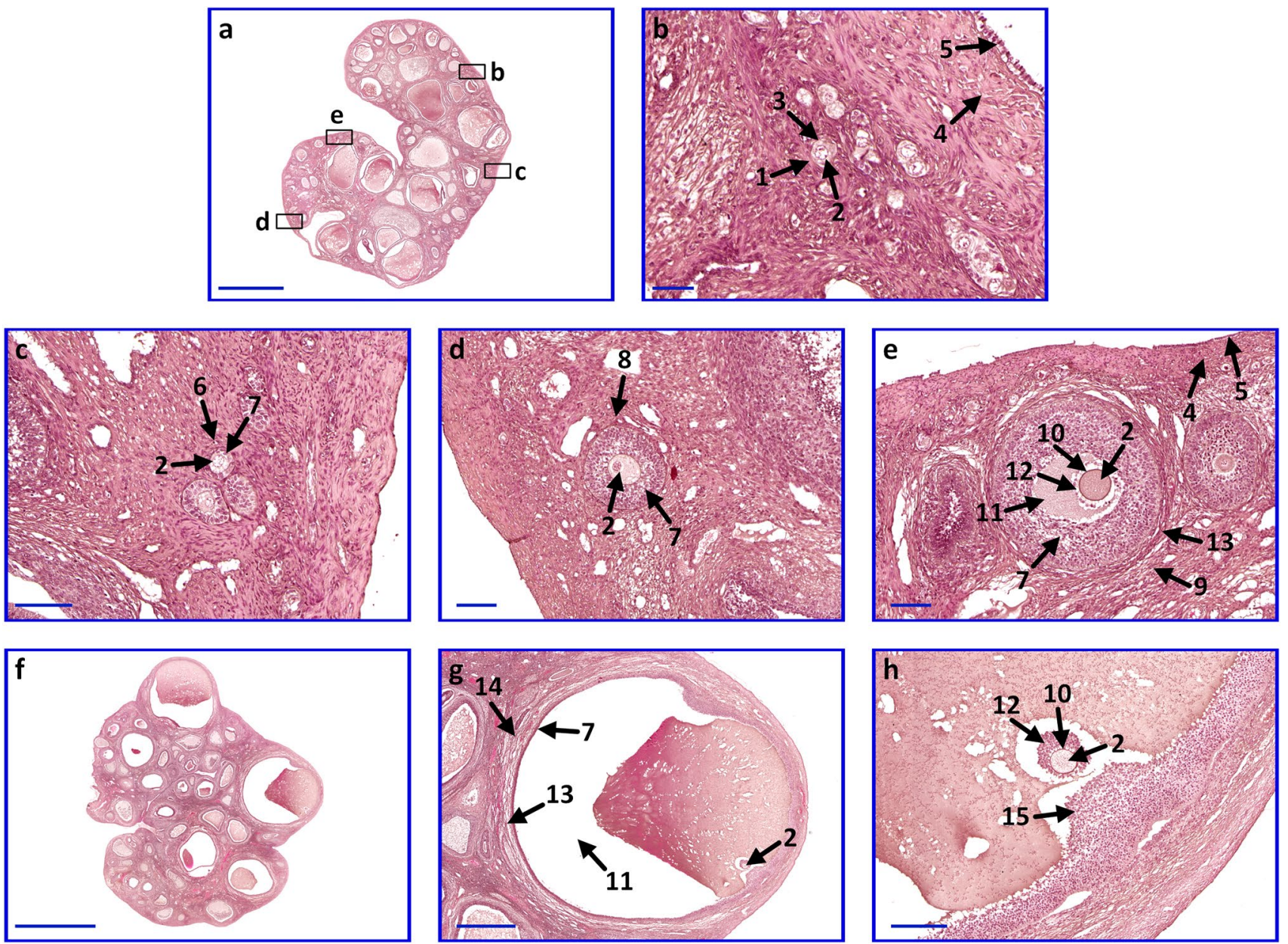

Fig. 3 Microphotograph representing ovaries with follicles in different stages of development. $\mathbf{a}-\mathbf{h}$ ovaries and follicles. Arrows: 1, primordial follicle; 2, oocyte; 3 , follicular cells; 4, tunica albuginea; 5 , germinal epithelium; 6 , unilaminar primary follicle; 7 , granulosa cells; 8 , multilaminar primary follicle; 9 , secondary follicle; 10 , zona pellucida; 11 , antrum; 12 , corona radiate; 13 , theca interna and theca externa; 14, Graafian follicle; 15, cumulus oophorus. Scale bar sizes: a, f $5000 \mu \mathrm{m} ; \mathbf{g} 1000 \mu \mathrm{m} ; \mathbf{h} 200 \mu \mathrm{m} ; \mathbf{c}-\mathbf{e} 100 \mu \mathrm{m} ; \mathbf{b} 50 \mu \mathrm{m}$ band and 635-713 nm detector for detection of chromatin. The 40× Leica HCX PL APO CS objective, pinhole, offsets, gain and AOBS were adapted. These parameters were kept throughout the whole experiment. The oocytes were scanned in equatorial optical sections, and microphotographs were saved and processed using the NIS-Elements AR 3.00 software (Laboratory Imaging).

The data were analysed with Fisher's least significant difference (LSD) test using ANOVA SPSS version 11.5 for Windows (SPSS, Inc., Chicago, IL, USA). Differences at $p<0.05$ were considered statistically significant. Differences at $p<0.05$ were considered statistically significant.

\section{Results}

Hematoxylin and eosin staining allowed to determine the histological structure of collected ovaries. Each of the samples revealed proper morphology. Follicles in different stages of development: primordial, primary unilaminar, primary multilaminar, secondary and Graafian follicle were noted (Fig. 3).

The results of lipid droplet examination indicate that the mean values of the total lipid composition for immature oocytes were higher than those in the mature oocytes. The total number of lipid droplets of immature porcine oocytes was significantly higher in comparison to oocytes with 
expanded cumulus (Fig. 4). During the process of maturation, the total number of lipid droplets decreased in oocytes in comparison to the germinal vesicle stage.

However, the results suggest that the areas covered with lipid droplets are similar in the immature and mature oocytes, indicating that the porcine oocytes contain a lower number of lipid droplets of larger surface after maturation (Fig. 4).

Whole transcriptome profiling by Affymetrix microarray allows the analysis of gene expression changes in freshly isolated oocytes, before in vitro procedure ("before IVM"), compared to after in vitro maturation ("after IVM"). Using
Affymetrix ${ }^{\circledR}$ Porcine Gene 1.1 ST Array we have examined expression of 12,258 porcine transcripts. Genes with a fold change higher than $|2|$ and with a corrected p-value lower than 0.05 were considered as differentially expressed, and there were 419 different transcripts revealed via the analysis. Subsequently, the genes were used for the identification of significantly enriched GO BP terms.

DAVID (Database for Annotation, Visualization and Integrated Discovery) software was used for extraction of the genes belonging to "cellular response to hormone stimulus" and "cellular response to unfolded protein" gene ontology Biological Process terms (GO BP). 25 genes from these GO
Fig. 4 Contents of lipid droplets during IVM. Representative images of porcine oocytes before (a) and after (b) in vitro maturation. Oocytes were stained by Nile red (red colour-lipid droplets). Scale bar represents $20 \mu \mathrm{m}$. (c) Number of lipid droplets in porcine oocytes before $(0 \mathrm{~h})$ and after maturation $(44 \mathrm{~h})$. The oocytes were examined by confocal microscopy after either collection or maturation in standard conditions. (d) Relative lipid area in an optical section of scanned porcine oocytes before $(0 \mathrm{~h})$ and after maturation (44 h).

The oocytes were examined by confocal microscopy after either collection or maturation in standard conditions. Values with different superscripts are significantly different $(\mathbf{a}, \mathbf{b}$, $p<0.05$ )
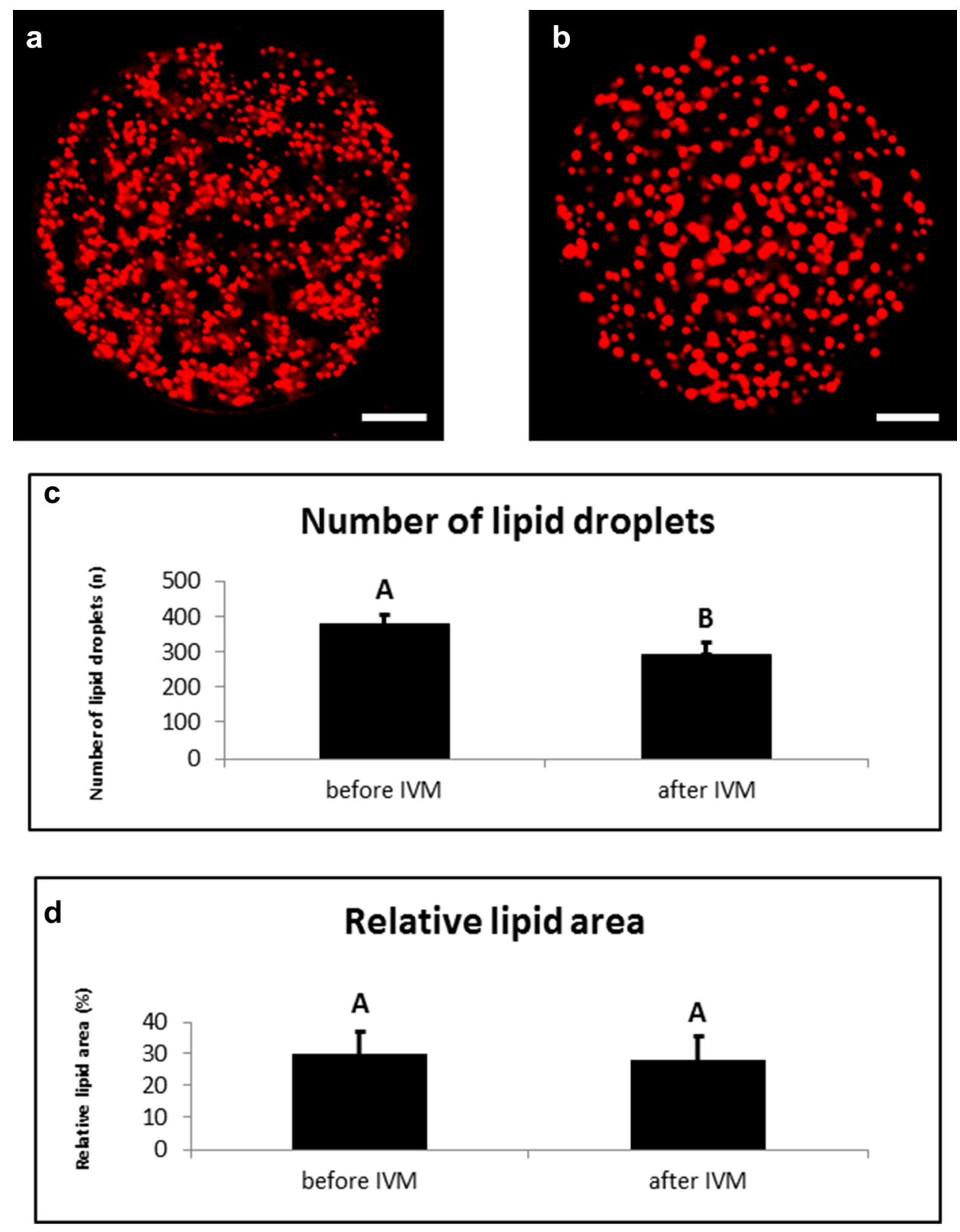
BP terms were significantly represented in down-regulated gene sets (Fig. 5).

The set of the differentially expressed genes belonging to "cellular response to hormone stimulus" and "cellular response to unfolded protein" GO BP terms with their official gene symbols, fold changes in expression and corrected $p$ values was also shown in Table 2 .

The enrichment of each GO BP term was calculated as a z-score and shown on the circle diagram (Fig. 6).

Moreover, in the Gene Ontology database, the genes that form one GO group can also belong to other different $\mathrm{GO}$ term categories. For this reason, we explore the gene intersections between selected GO BP terms. The relation between those GO BP terms was presented as a circle plot (Fig. 7) as well as a heatmap (Fig. 8). Most of the presented genes belong to one of the GOs of interest. Only two of the genes: INSR and FOS, are members of both of the analysed gene ontologies.

STRING-generated interaction network was created between differentially expressed genes belonging to the studied ontology terms. The intensity of the edges reflects the strength of the interaction score (Fig. 9). The functional interactions between chosen genes were investigated using the REACTOME FIViz app to the Cytoscape 3.6.0 software. The results were shown in Fig. 10.

\section{cellular response to hormone stimulus}

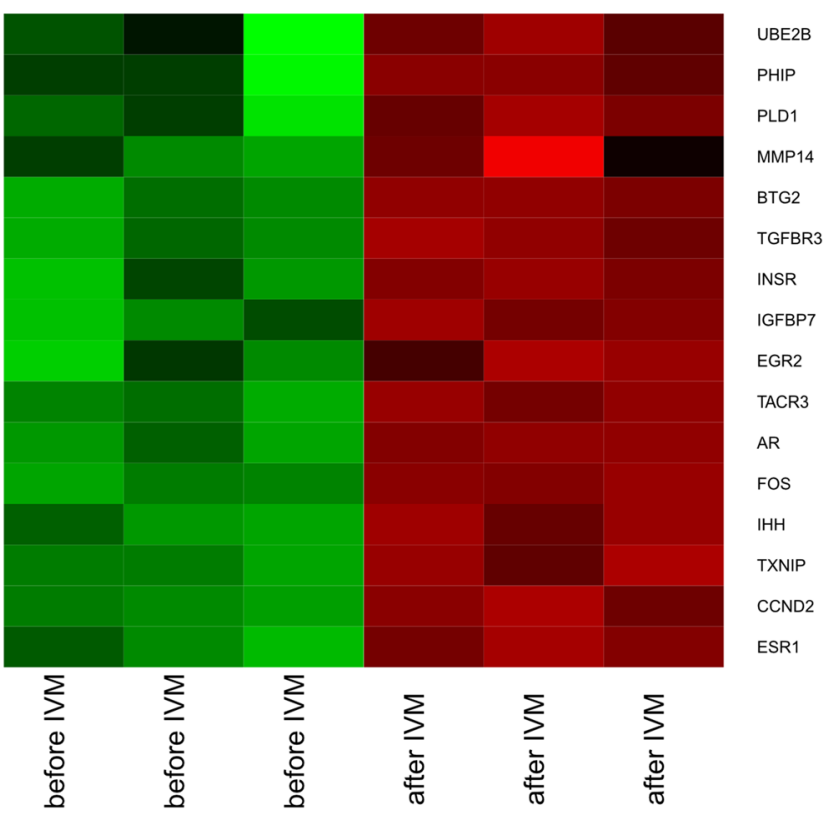

Fig. 5 Heat map representations of differentially expressed genes belonging to the "cellular response to hormone stimulus" and "cellular response to unfolded protein" GO BP terms. Arbitrary signal intensity acquired from microarray analysis is represented by colours
Microarray results were validated using RT-qPCR (Fig. 11), and the differential regulation of genes was confirmed via both methodologies. However, the scale of changes of some of the genes varies between the methods, which may be explained through their different sensitivity and specificity. All of presented genes showed the same pattern of expression as in the microarray analysis.

\section{Discussion}

Molecular interactions with the surrounding somatic cells are a key element during oocyte maturation in the course of folliculogenesis process (Chermuła et al. 2019). There are already many reports of these dependencies, but they are still not well understood. The possibilities offered by the analysis of gene expression using the microarray technique allowed to define and determine the processes occurring during the development of ovarian follicles (Bryja et al. 2018; Chermuła et al. 2018). Microarray technology provides a comprehensive analysis of tissue transcriptome and is a tool that creates the possibility of understanding molecular bases and relationships between the genes driving physiological and pathophysiological processes. Transcriptomic analysis was carried out on two groups of

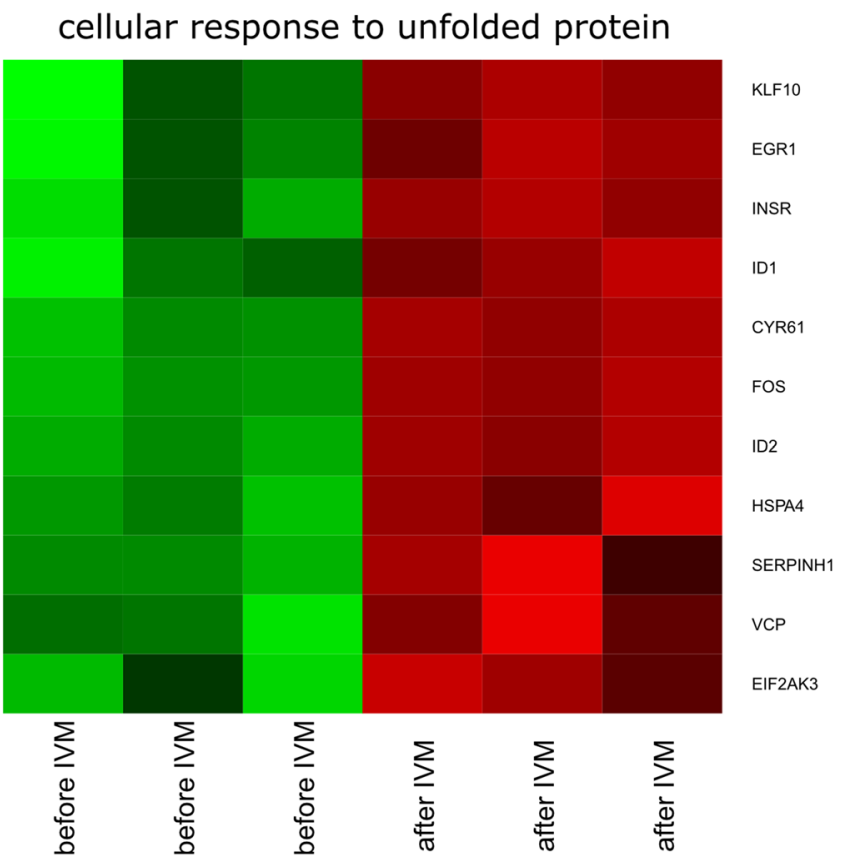

(green, higher; red, lower expression). Log2 signal intensity values for any single gene were resized to Row Z-Score scale (from - 2, the lowest expression to +2 , the highest expression for a single gene) 
Table 2 Gene symbols, fold changes in expression and corrected $\mathrm{p}$ values of studied genes

\begin{tabular}{lllr}
\hline Gene & Fold change & Adj. $p$ value & Entrez gene ID \\
\hline$A R$ & 0.105986 & 0.000138 & 397582 \\
$B T G 2$ & 0.074386 & $9.55 \mathrm{E}-05$ & 100048932 \\
CCND2 & 0.121809 & 0.000179 & 397162 \\
CYR61 & 0.080657 & $7.54 \mathrm{E}-05$ & 100153791 \\
EGR1 & 0.376128 & 0.005477 & 100520726 \\
EGR2 & 0.165504 & 0.00795 & 100038004 \\
EIF2AK3 & 0.41889 & 0.008422 & 100513348 \\
ESR1 & 0.08163 & 0.000522 & 397435 \\
FOS & 0.052794 & $4.74 \mathrm{E}-05$ & 100144486 \\
HSPA4 & 0.441182 & 0.002321 & 100524853 \\
ID1 & 0.335473 & 0.003974 & 100522839 \\
$I D 2$ & 0.06298 & $4.74 \mathrm{E}-05$ & 654298 \\
$I G F B P 7$ & 0.40376 & 0.002496 & 100302573 \\
$I H H$ & 0.304996 & 0.000551 & 397174 \\
$I N S R$ & 0.316016 & 0.001913 & 396755 \\
KLF10 & 0.405439 & 0.006845 & 100153665 \\
MMP14 & 0.488721 & 0.03806 & 397471 \\
PHIP & 0.385682 & 0.021116 & 100155644 \\
PLD1 & 0.468342 & 0.011045 & 100519446 \\
SERPINH1 & 0.467321 & 0.006338 & 396773 \\
TACR3 & 0.11506 & 0.000148 & 100521983 \\
TGFBR3 & 0.196522 & 0.000406 & 397512 \\
TXNIP & 0.355539 & 0.000781 & 733688 \\
UBE2B & 0.38278 & 0.041105 & 100513527 \\
VCP & 0.435612 & 0.007402 & 397524 \\
\hline & & & \\
\hline
\end{tabular}

oocytes: before and after the in vitro maturation process. Additionally, to confirm their metabolic maturity, lipid profile was determined in pre-mature oocytes, as well as those subjected to in vitro maturation. The results of the analysis provided a possible confirmation of oocyte maturity (as illustrated by lipid droplets reduction after oocyte maturation) with a method independent of molecular maturation. Furthermore, histological staining of sample ovaries serving as a source of the oocytes analyzed in this study was performed. The resulting figures aim to confirm the proper physiology of the ovarian tissues, as well as visualize the location of the maturing oocyte in the growing follicle in in vivo conditions.

The analysis of genes belonging to the "Cellular response to hormone stimulus" and "Cellular response to unfolded protein" ontology groups was the focus of the current study. These two gene groups may be directly or indirectly involved in signal transduction during oocyte maturation in both in vivo and in vitro (IVM) conditions.
Examination of all the 25 genes of interest allowed to observe a reduced level of expression after IVM in all of them. In total, from 25 differentially expressed genes, ten: FOS, ID2, BTG2, CYR61, ESR1, AR, TACR3, CCND2, $E G R 2$ and $T G F B R 3$, were identified as being significantly downregulated after in vitro maturation.

The first of the analyzed genes, with the largest change in expression after the maturation process, is FOS (Fos proto-oncogene) gene. The protein encoded by this gene, together with other proteins, forms the AP-1 transcription factor subunit (Borys et al. 2018).

One of the most important functions of this gene is cell differentiation, transformation and proliferation (Krishna et al. 2018). It has been suggested that the expression of this gene drastically increases in ovulatory follicles after administration of human chorionic gonadotropin (hCG). It is one of the key ovulatory genes required to increase the level of prostaglandins (PG) during ovulation in human granulosa cells (Choi et al. 2018). Earlier reports indicate the presence of FOS transcripts in germinal vesicles (GV) and metaphase II (MII) oocytes (Regassa et al. 2011). Decreased level of FOS gene expression after oocyte maturation observed in this study confirms the results presented by Blaha et al. (2015). These results prove that the amount of FOS mRNA rapidly and dramatically decreases during the first hour of the oocytecumulus complex (COC) culture. It was noted that FOS mRNA concentration gradually decreased throughout the entire culture period. These combined results may prove that in MII stage oocytes, the demand for FOS transcripts is at a much lower level than in the immature COCs. Considering the above, the most important function of this gene is the regulation of hormone stimulation and protein signaling activation during oocyte maturation process in growing ovarian follicles.

The second most downregulated gene, present only in "Cellular response to unfolded protein" ontology group, is ID2 (inhibitor of DNA binding 2). ID2 encodes a protein with a negative effect on cellular differentiation (Massari and Murre 2000). In ovarian follicles, the highest level of ID2 protein is observed in granulosa cells, with expression of this gene stimulated by GDF9 (growth differentiation factor 9) and BMP15 (bone morphogenetic protein 15). In addition, FSH promotes $I D 2$ expression in porcine granulosa cells (Blaha et al. 2015). In poultry, ID2 mRNA is involved in control and differentiation of follicles, as well as differentiation of granulosa cells. Hogg et al. (2010) suggested that ID proteins play one of the main roles in growth regulation and differentiation of ovarian steroidogenic cells. Expression of ID family proteins is, in various ways, regulated by members of the TGF $\beta$ family 


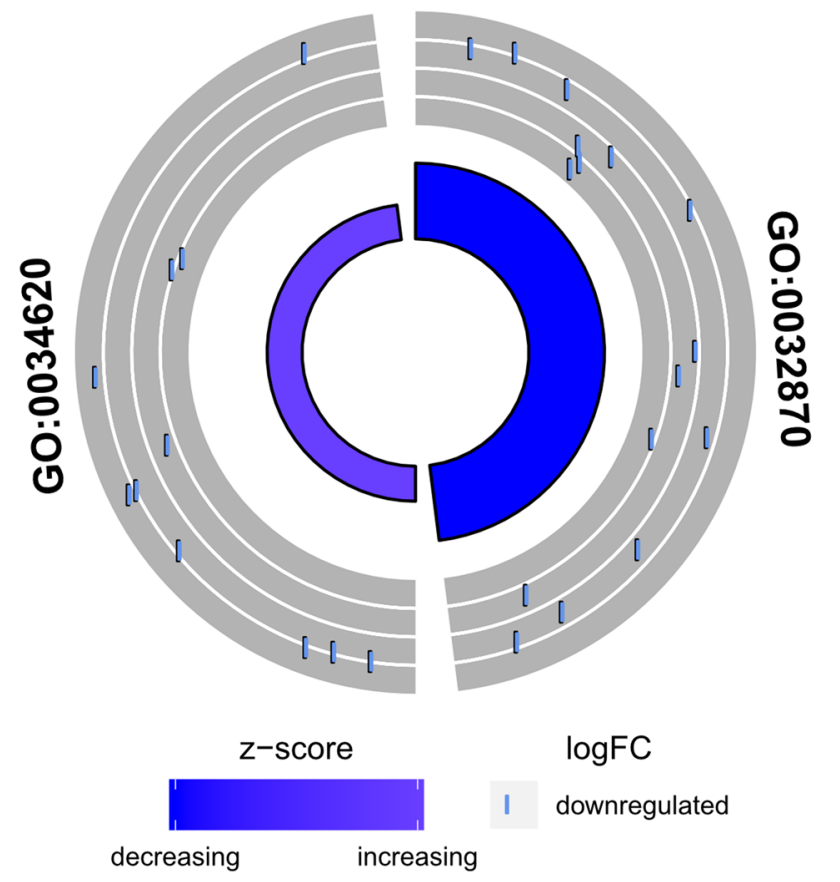

Fig. 6 The circle plot showing the differently expressed genes and z-score "cellular response to hormone stimulus" and "cellular response to unfolded protein". The outer circle shows a scatter plot for each term of the fold change of the assigned genes. Purple circles

through intracellular SMAD signaling pathways. Lower ID2 gene expression, observed in the "after IVM" group of oocytes, may result from the fact that expression of ID proteins in growing in vivo ovarian follicles is subject to paracrine stimulation through activation of activin and/ or BMPs through the SMAD signaling pathway (Zhang et al. 2018).

The gene of the third most changed expression, a member of "cellular response to hormone stimulus" ontology group, is BTG2 (anti-proliferation factor 2). The protein encoded by this gene has antiproliferative properties. BTG2 proteins were involved in the regulation of the G1/S stage transition during the cell cycle. Reduced expression of this gene is observed in human tumors, possibly due to weak differentiation of tumor cells $(\mathrm{Hu}$ et al. 2013). It has also been proven that $B T G 2$ can direct cells towards the apoptotic process (Kranc et al. 2018). The ovarian inflow of LH induces the expression of BTG family proteins that play an important role in the transfer of follicular granulosa cells into luteal phase through regulation of kinetics of their cell cycle. The low level of gene expression observed in mature oocytes is due to the fact that oocytes do not have apoptotic properties and display up-regulation and blue ones down-regulation. The inner circle shows the z-score of each GO BP term. The width of each bar corresponds to the number of genes within GO BP term and the color corresponds to the $\mathrm{z}$-score

do not differentiate into cells with different traits during the course of obtaining cellular maturity for fertilization (Kranc et al. 2018). CYR61 (cysteine-rich angiogenic inducer 61) encodes a proliferation and adhesion mediating protein expressed on the cell surface. Reduced expression of CYR61 is noted in tumor tissues (Chien et al. 2004). CYR61 is a potential molecular mediator of the CL (corpus luteum) angiogenesis. Steroidogenic and endothelial cells of the corpus luteum are a source of CYR61 expression (Chermuła et al. 2019). Reduction of this gene's expression results in partial oocyte separation from the surrounding granulosa cells causing the loss of bi-directional communication with future CL.

The six other analyzed genes, such as BTG2, only belong to the ontological group representing the genes responsible for "cellular response to hormone stimulus". ESR1 (estrogen receptor 1), responsible for the expression of proper estrogen receptors encodes a DNA binding protein activating the transcription process. After estrogen is bound to the ESR1 receptor, the metabolic pathway responsible for ovarian follicle maturation begins. The highest level of ESRI expression was observed in the fetal period in the nuclei of growing oocytes (Chen et al. 


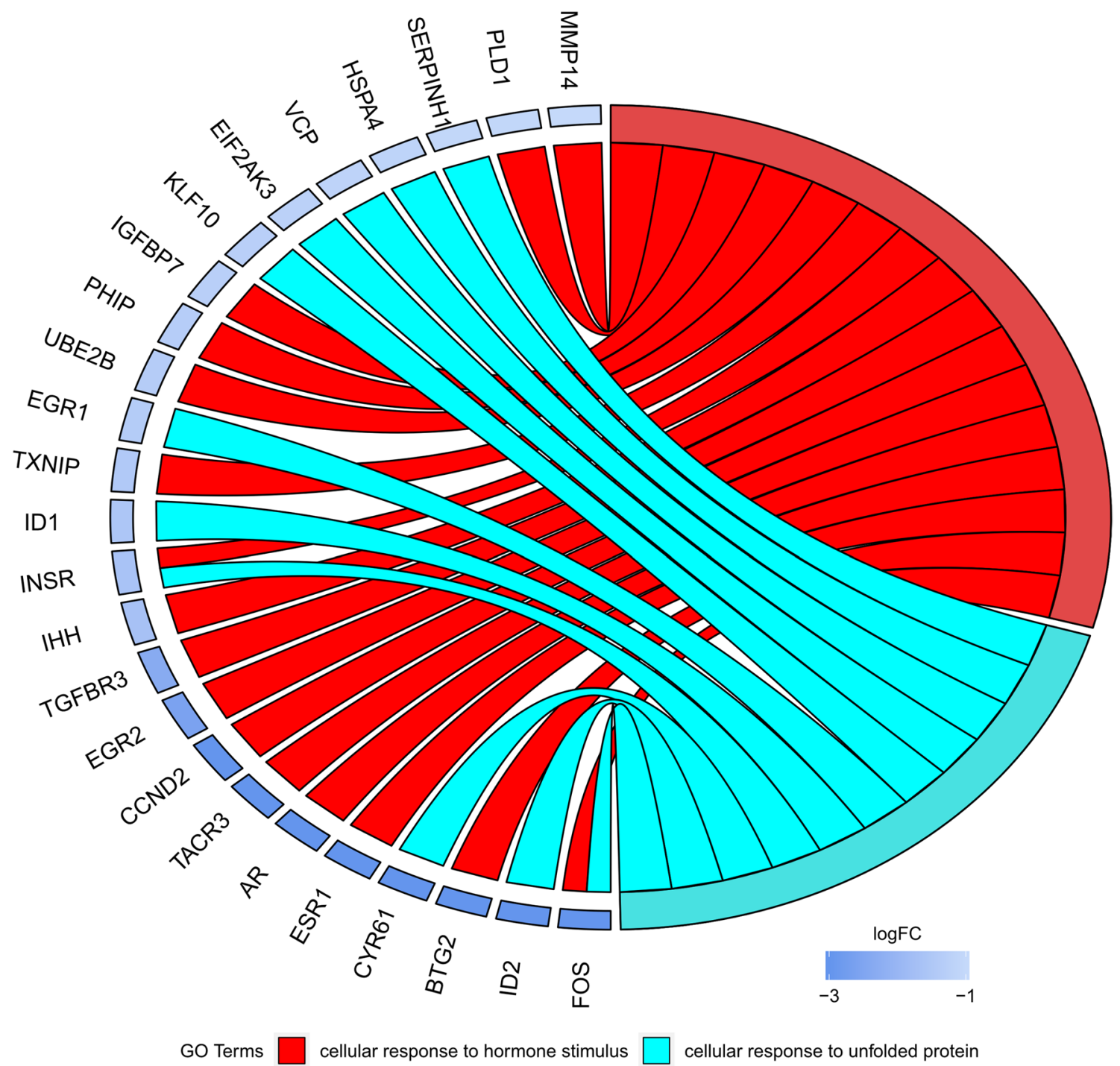

Fig. 7 The representation of the mutual relationship between differently expressed genes that belong to the "cellular response to hormone stimulus" and "cellular response to unfolded protein". The rib- bons indicate which gene belongs to which categories. The middle circle represents logarithm from fold change (LogFC) after IVM. The genes were sorted by $\log \mathrm{FC}$ from most to least changed gene

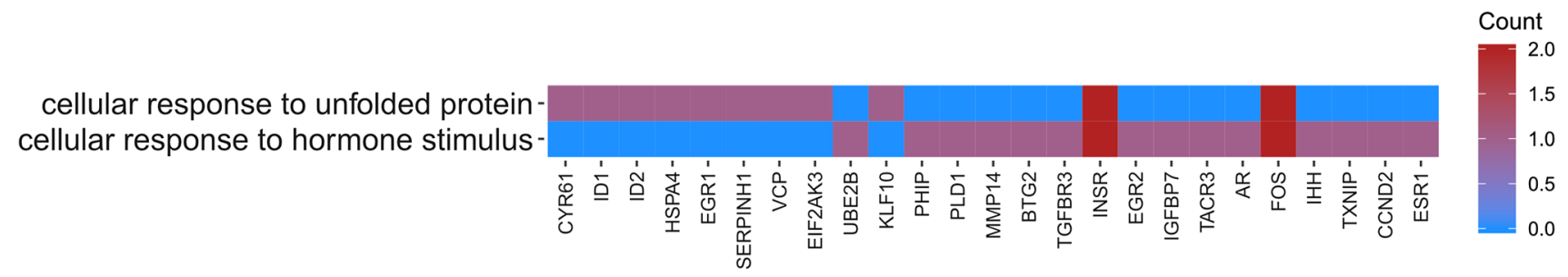

Fig. 8 Heatmap showing the gene occurrence between differently expressed genes that belongs to the "cellular response to hormone stimulus" and "cellular response to unfolded protein". The red color is associated with gene occurrence in the GO Term. The intensity of the color is corresponding to the amount of GO BP terms that each gene belongs to 


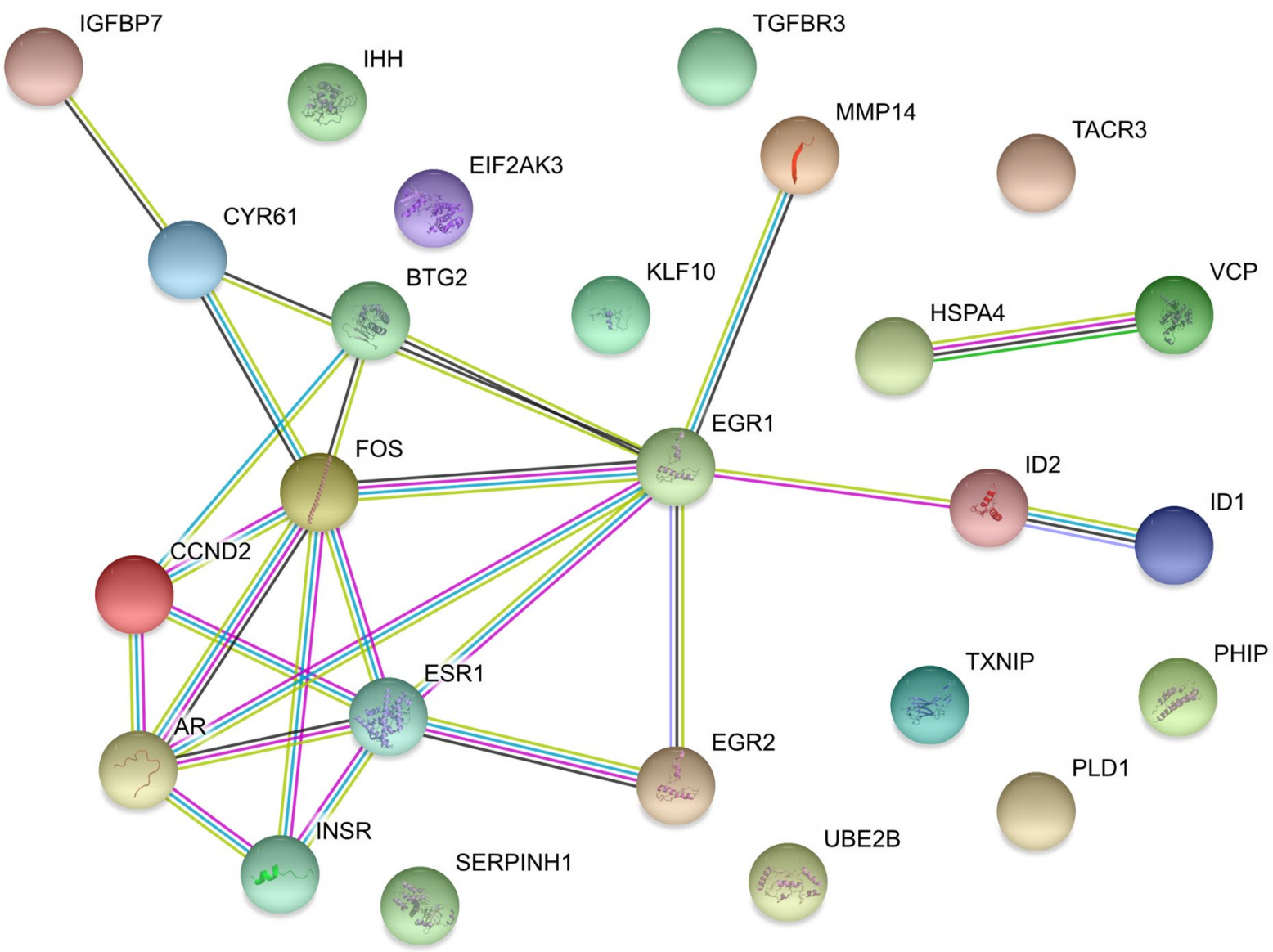

Known interaction

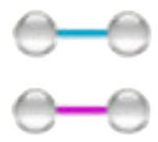

from curated databases

experimentally determined
Predicted interactions

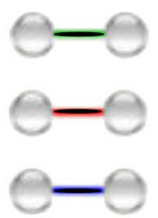

gene neighborhood

gene fusions

gene co-occurrence
Others

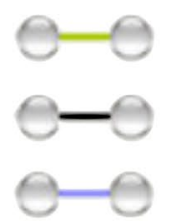

textmining

co-expression

protein homology

Fig. 9 STRING-generated interaction network between genes that belongs to the "cellular response to hormone stimulus" and "cellular response to unfolded protein". The intensity of the edges reflects the strength of the interaction score

2009). Lower ESRl gene expression in mature oocytes confirms its decline during the maturation process and highest level at early stages of folliculogenesis. Other data suggest that reduction of ESR1 may be correlated with oocyte size and may lead to changes in the activity of the PI3K/AKT pathway (Artini et al. 2017). The ESRl gene is co-expressed with the next two identified genes: $A R$ (androgen receptor) and $E G R 2$ (early growth response 2). $A R$ carries information about a two-domain transcriptional activator protein (composed of androgen receptor and DNA binding domain). Androgen receptors play a key role in primary ovarian follicles (Ma et al. 2017). The action of androgens on early stages of folliculogenesis and their simultaneous expression with $I G F 1 R, I G F 2$, and $I G F B P 3$ appears to be necessary for the early primordial ovarian follicle activation. EGR2 encodes a transcription factor consisting of the three tandem $\mathrm{C} 2 \mathrm{H} 2$-type zinc fingers. EGR gene family is responsible for the differentiation processes, managing growth and cellular functions. Decreased expression of the $E G R 2$ gene in mature oocytes confirms the results presented by Celichowski et al. in maturing oocytes, EGR2 shows a notably stronger inhibitory effect 


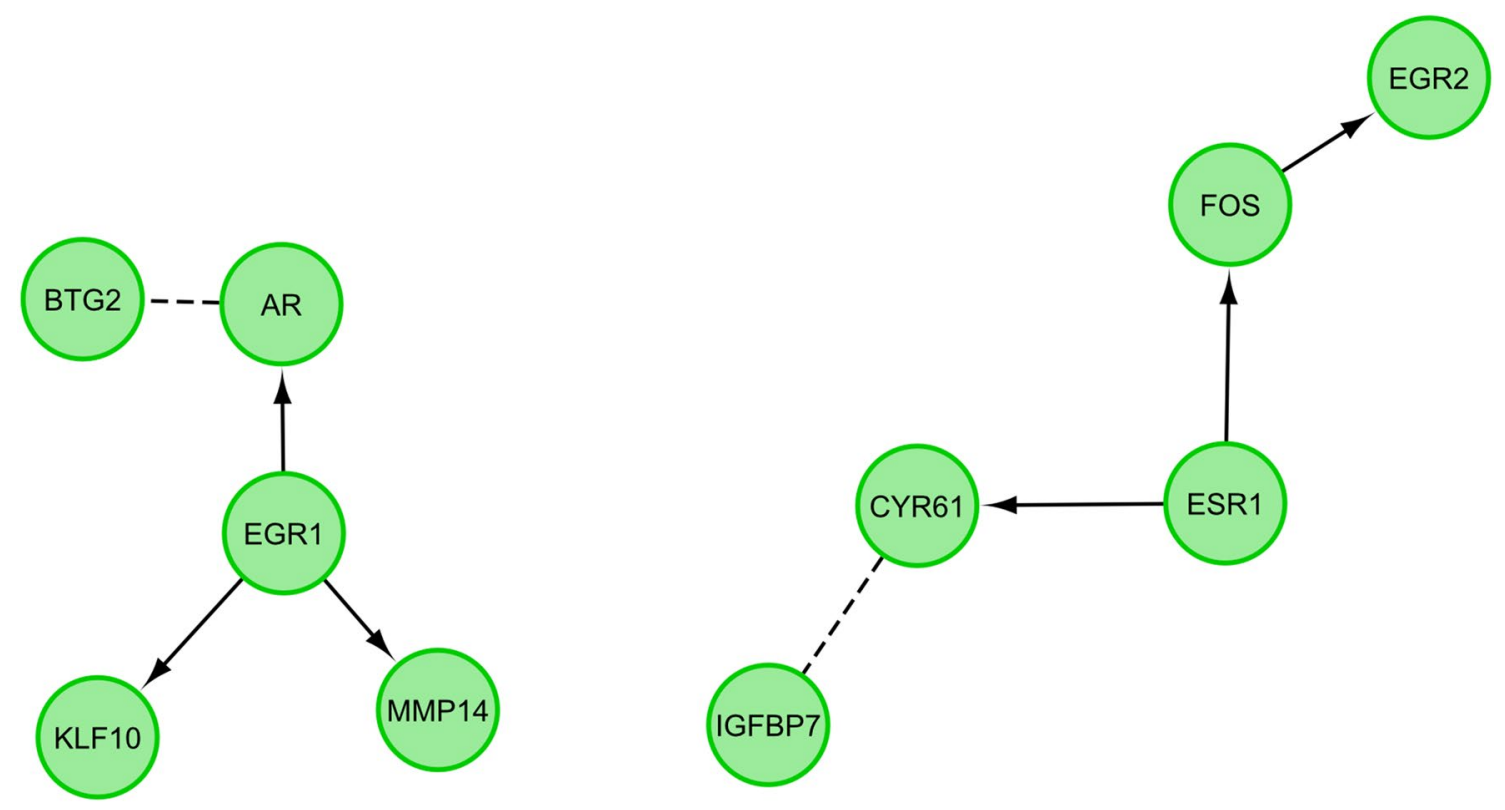

Fig. 10 Functional interaction (FI) between genes that belongs to the "cellular response to hormone stimulus" and "cellular response to unfolded protein". In the following figure " $\rightarrow$ " stands for activating/catalyzing inputs, and "---" for predicted FIs

on gene expression as compared to EGRl (Celichowski et al. 2018).

Tachykinin receptor 3 (TACR3) carries information about the neurokinin $\mathrm{B}$ receptor. TACR3 is a $\mathrm{G}$ proteincoupled receptor, mainly expressed by Leydig cells in the testis (Topaloglu et al. 2009). Inhibition of TACR3 expression in the early ovary by Wnt-4 can promote female sex determination (Vainio et al. 1999). Mutations associated with loss of TAC3/TACR 3 gene functions cause IHH (isolated hypogonadotropic hypogonadism), characterized by a lack of sexual maturation and low circulating levels of LH and gonadal steroids (Young et al. 2010). Cyclin D2 (CCND2) is responsible for ovarian cell proliferation, most notably regulating the $\mathrm{G} 1 / \mathrm{S}$ phase transition during the cell cycle. The highest level of its transcripts was observed in ovarian and testicle tumor cells (Tan et al. 2005). In embryonic development, a high rate of $C C N D 2$ expression and proliferation is observed during early cortex and ovarian cord formation. Higher levels of CCND2 expression were also observed at the beginning of pregnancy (Hummitzsch et al. 2019). During folliculogenesis, $C C N D 2$ plays a key role in the proliferation of cumulus oophorus cells. Null mutation and block of $C C N D 2$ expression in mice undermines the proliferation of cumulus cells, resulting in the growth of small follicles that are unable to ovulate (Sicinski et al. 1996). Increased expression of CCND2, as well as CTNND1 (catenin delta 1), is inhibited by LH through the activation of CD44 (van Montfoort et al. 2008). So far, there is no clear information about the cause of this gene's expression in oocytes. The presence of CCND2 mRNA transcripts may be the result of their transport inside the oocyte in the process of two-way communication with the surrounding cumulus cells. The last of ten genes that were identified as differentially expressed is TGFBR3 (transforming growth factor beta receptor 3). TGFBR3 may be as a mediator of cancer progression and epithelial to mesenchymal transition factor. Beta-glycan encoded by this gene mediates signal transduction by members of the TGF $\beta$ (transforming growth factor- $\beta$ ) superfamily. In the group of CCs subjected to temporary hypoxia, increased expression of this gene was observed (Al-Edani et al. 2014). The decrease in TGFBR3 expression in oocytes after IVM may be caused by the fact that the oocyte itself is not 
involved in the formation of corpus luteum blood vessels, for which the TGFBR3 is largely responsible (Chermuła et al. 2018; Sarraj et al. 2007).

Lipid droplets in oocytes are important organelles for embryonal development of porcine embryos. Previously it was reported that removal of cytoplasmic lipid droplets (delipidation) in porcine embryos decrease the extent of injury during cryopreservation and enhance tolerance of porcine oocytes to chilling (Nagashima et al. 1994). However, delipidation itself could compromise embryo viability, as intracellular lipids are a source of oocyte energy and exist as complexes of "smooth endoplasmaic reticulum-lipid globules-mitochondria" in cells (Sathananthan 1994). Lipid droplets are the main source of energy for embryonic development (Sturmey and Leese 2003), and their number and distribution patterns in oocytes and embryos have been reported linked to the developmental competence of early embryos through the blastocyst stage (Yoneda et al. 2004). It was presented that delipation of oocytes had no effect on the cleavage ability of the partnenogenetic porcine embryos during the early developmental stages (2-cell and 4-cell stages), but the ability to form a blastocyst was significantly reduced, perhaps, because of the reduction in available lipid droplets and mitochondria or both (Niu et al. 2015). Lipid composition deposited in the oocyte has been shown to be accumulated during follicular development (Fair et al. 1997). Hyttel et al. (1997) observed that at the GVBD stage lipid droplets within the oocyte cytoplasm are increased in number and size. The total area of lipid droplets was similar between GV stage and in vitro matured oocytes, contrary to a number of lipid droplets. The number of lipid droplets decreased during the process of maturation, with their surface area progressively increasing. Niimura et al. (2002) consider that the increase in the number of lipid droplets in porcine oocytes is closely related to the resumption of meiotic maturation, regardless of in vivo or in vitro maturation. Our findings indicate that during in vitro maturation oocyte metabolized primary small lipid droplets. The total lipid content may have a potential role as reserve fuel and have decreases over the course of oocyte maturation in vitro.

Overall, this study paid particular attention to the comparison of expression of genes directly or indirectly involved in hormonal regulation of oocytes, as well as protein signaling pathways. After IVM, downregulation of expression was observed in all of the 25 analyzed genes belonging to two ontological groups: cellular response to hormone stimulus (GO:0032870) and cellular response to unfolded protein (GO:0034620). Next, 10 genes were identified as being the most altered in expression after the IVM process, with a possibility of playing key roles during COCs maturation. While maturation of oocytes in in vitro culture only allows for an approximate way to determine the levels of transcripts similar to those observed in in vivo conditions, it is still the best way to predict their developmental potential. The sensitivity of oocytes to changing the hormonal environment, as well as the basic pathways of cell signaling are both necessary for processes enabling the oocyte to be fertilized. The environment of oocyte growth is one of the most important factors in its development and maturation. The results may contribute to the broadening of knowledge about the processes associated with in vitro growth and maturation of oocytes.

Our research enabled identification and detailed genes expression analysis, which regulate very important for oocyte maturation cellular response to hormone stimulus and unfolded protein processes. The use of IVM in porcine oocytes can significantly contribute to the deepening of our knowledge about mechanisms regulating oocyte maturation resumption. Our research results in an animal model can significantly contribute to increasing the efficiency of in vitro maturation of human oocytes. IVM gives the possibility of increased ART safety in patients with PCOS. Another advantages of this method over controlled ovarian stimulation (COS) include lower drug costs and reduced treatment time.

Additionally, it also presents results of lipid droplet distribution and size analysis between immature and mature oocytes, potentially describing an interesting, non-transcriptomic approach of oocyte maturity determination. However, it needs to be noted that this manuscript presents an entry-level study, which, considering the high complexity of oocyte maturation, fertilization and early embryonic development processes, will certainly require further proteomic analysis to fully confirm the results and understand the processes that underlie the observed changes. The results of this study aim to serve as a basic molecular reference for further analyses that will be performed in the further stages of the project, potentially ultimately leading to improvement of understanding of the processes associated with important steps of assisted reproduction techniques. 


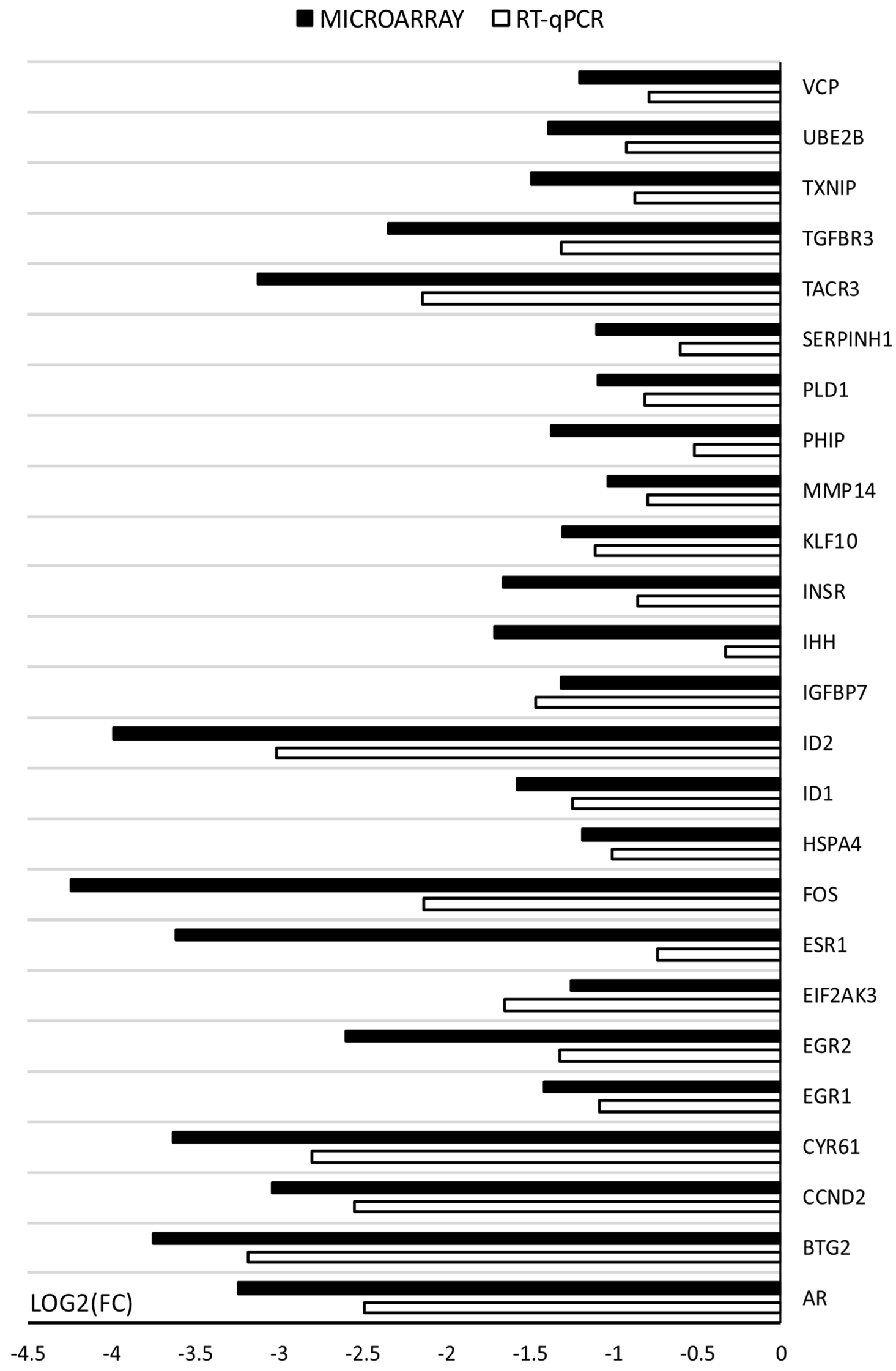


4Fig. 11 Comparison of gene expression analysis of oocytes before $\operatorname{IVM}(3 \times n=50)$ and after IVM $(3 \times n=50)$ using microarray assay and RT-qPCR. RT-qPCR analysis was normalized to the expression of three housekeeping genes (PBGD, $\beta$-actin, $18 \mathrm{~S}$ rRNA). All of the differences in expression were statistically significant at: $p<0.05$

Acknowledgements Supported by the Ministry of Health, Czech Republic - conceptual development of research organization ( $\mathrm{FNBr}$, 65269705), project MSMT LTC 18059 and fund from the Faculty of Medicine MU to junior researcher Michal Jeseta. The authors are active participants of the COST Action CA16119 (In vitro 3-D total cell guidance and fitness). This publication and its results are an outcome of a cooperation between Poznan University of Medical Sciences (Poznań, Poland) and Polish Ministry of Science and Higher Education, with Institute of Advanced Sciences Sp. z o.o. (Poznań, Poland), as a part of the "Professional PhD" program.

Author contributions Conceptualization, BC, HP-K, MM and LP; data curation, AK, WK; formal analysis, BC, MJ, PA, DB, IM, DI and BK; funding acquisition, MJ; Investigation, BC, WK; HP-K; methodology, PS-K, IK, PC, MZ; project administration, PA, LP, and BK; software, MJ, PC, and IM; supervision, PA, DB, IM, MM, DI, MZ, PM and BK; validation, IK, HP-K; visualization, PS-K, AK, MJ and PC; writing, BC; writing—review \& editing, BK.

\section{Compliance with ethical standards}

Conflicts of interest The authors declare no conflict of interest.

Open Access This article is licensed under a Creative Commons Attribution 4.0 International License, which permits use, sharing, adaptation, distribution and reproduction in any medium or format, as long as you give appropriate credit to the original author(s) and the source, provide a link to the Creative Commons licence, and indicate if changes were made. The images or other third party material in this article are included in the article's Creative Commons licence, unless indicated otherwise in a credit line to the material. If material is not included in the article's Creative Commons licence and your intended use is not permitted by statutory regulation or exceeds the permitted use, you will need to obtain permission directly from the copyright holder. To view a copy of this licence, visit http://creativecommons.org/licenses/by/4.0/.

\section{References}

Al-Edani T, Assou S, Ferrières A, Bringer Deutsch S, Gala A, Lecellier C-H, Hamamah S et al (2014) Female Aging alters expression of human cumulus cells genes that are essential for oocyte quality. Biomed Res Int. https://doi.org/10.1155/2014/964614

Artini PG, Tatone C, Sperduti S, D’Aurora M, Franchi S, Di Emidio G, Gatta V et al (2017) Cumulus cells surrounding oocytes with high developmental competence exhibit down-regulation of phosphoinositol 1, 3 kinase/protein kinase B (PI3K/AKT) signalling genes involved in proliferation and survival. Hum Reprod 32(12):24742484. https://doi.org/10.1093/humrep/dex320

Blaha M, Nemcova L, Kepkova KV, Vodicka P, Prochazka R (2015) Gene expression analysis of pig cumulus-oocyte complexes stimulated in vitro with follicle stimulating hormone or epidermal growth factor-like peptides. Reprod Biol Endocrinol 13(1):113. https://doi.org/10.1186/s12958-015-0112-2
Borys-Wójcik S, Kocherova I, Celichowski P, Popis M, Jeseta M, Bukowska D, Kempisty B et al (2018) Protein oligomerization is the biochemical process highly up-regulated in porcine oocytes before in vitro maturation (IVM). Med J Cell Biol 6(4):155-162. https://doi.org/10.2478/acb-2018-0025

Borys S, Brązert M, Jankowski M, Kocherova I, Ożegowska K, Celichowski P, Kempisty B et al (2018) Enzyme linked receptor protein signaling pathway is one of the ontology groups that are highly up-regulated in porcine oocytes before in vitro maturation. J Biol Regul Homeost Agents 32(5):21-35

Bradley J, Pope I, Masia F, Sanusi R, Langbein W, Swann K, Borri P (2016) Quantitative imaging of lipids in live mouse oocytes and early embryos using CARS microscopy. Dev (Cambrid) 143(12):2238-2247. https://doi.org/10.1242/dev.129908

Bryja A, Dyszkiewicz-Konwińska M, Jankowski M, Celichowski P, Stefańska K, Chamier-Gliszczyńska A, Kempisty B et al (2018) Ion homeostasis and transport are regulated by genes differentially expressed in porcine buccal pouch mucosal cells during long-term culture in vitro-a microarray approach. Med J Cell Biol. https://doi.org/10.2478/acb-2018-0013

Budna J, Bryja A, Celichowski P, Kahan R, Kranc W, Ciesiółka S, Kempisty B et al (2017) Genes of cellular components of morphogenesis in porcine oocytes before and after IVM. Reproduction 154(4):535-545. https://doi.org/10.1530/REP-17-0367

Budna J, Celichowski P, Bryja A, Jeseta M, Jankowski M, Bukowska D, Kempisty B et al (2018) Expression changes in fatty acid metabolic process-related genes in porcine oocytes during in vitro maturation. Med J Cell Biol. https://doi.org/10.2478/ acb-2018-0009

Celichowski P, Nawrocki MJ, Dyszkiewicz-Konwińska M, Jankowski M, Budna J, Bryja A, Kempisty B et al (2018) "Positive regulation of RNA metabolic process" ontology group highly regulated in porcine oocytes matured in vitro : a microarray approach. Biomed Res Int 2018:1-10. https://doi. org/10.1155/2018/2863068

Chamier-Gliszczyńska A, Brązert M, Sujka-Kordowska P, Popis M, Ożegowska K, Stefańska K, Kempisty B et al (2018) Genes involved in angiogenesis and circulatory system development are differentially expressed in porcine epithelial oviductal cells during long-term primary in vitro culture - a transcriptomic study. Med J Cell Biol 6(4):163-173. https://doi.org/10.2478/acb-2018-0026

Chen Y, Breen K, Pepling ME (2009) Estrogen can signal through multiple pathways to regulate oocyte cyst breakdown and primordial follicle assembly in the neonatal mouse ovary. J Endocrinol 202(3):407-417. https://doi.org/10.1677/JOE-09-0109

Chermuła B, Brązert M, Iżycki D, Ciesiółka S, Kranc W, Celichowski P, Kempisty B et al (2019) New gene markers of angiogenesis and blood vessels development in porcine ovarian granulosa cells during short-term primary culture in vitro. Biomed Res Int 2019:6545210. https://doi.org/10.1155/2019/6545210

Chermuła B, Brązert M, Jeseta M, Ożegowska K, Sujka-Kordowska P, Konwerska A, Kempisty B et al (2018) The Unique mechanisms of cellular proliferation, migration and apoptosis are regulated through oocyte maturational development-a complete transcriptomic and histochemical study. Int J Mol Sci 20(1):84. https://doi. org/10.3390/ijms20010084

Chien W, Kumagai T, Miller CW, Desmond JC, Frank JM, Said JW, Koeffler HP (2004) Cyr61 suppresses growth of human endometrial cancer cells. J Biol Chem 279(51):53087-53096. https://doi. org/10.1074/jbc.M410254200

Choi Y, Rosewell KL, Brännström M, Akin JW, Curry TE, Jo M (2018) FOS, a critical downstream mediator of PGR and EGF Signaling necessary for ovulatory prostaglandins in the human ovary. J Clin Endocrinol Metabol 103(11):4241-4252. https://doi.org/10.1210/ jc.2017-02532 
Chomczynski P, Sacchi N (1987) Single-step method of RNA isolation by acid guanidinium thiocyanate-phenol-chloroform extraction. Anal Biochem 162(1):156-159. https://doi.org/10.1016/00032697(87)90021-2

Chronowska E (2014) High-throughput analysis of ovarian granulosa cell transcriptome. Biomed Res Int 2014:213570. https://doi. org/10.1155/2014/213570

Dias FCF, Khan MIR, Sirard MA, Adams GP, Singh J (2018) Transcriptome analysis of granulosa cells after conventional vs long FSH-induced superstimulation in cattle. BMC Genomics 19(1):258. https://doi.org/10.1186/s12864-018-4642-9

Fair T, Hulshof SCJ, Hyttel P, Greve T, Boland M (1997) Oocyte ultrastructure in bovine primordial to early tertiary follicles. Anat Embryol 195(4):327-336. https://doi.org/10.1007/s004290050 052

Hogg K, Etherington SL, Young JM, McNeilly AS, Duncan WC (2010) Inhibitor of differentiation (Id) genes are expressed in the steroidogenic cells of the ovine ovary and are differentially regulated by members of the transforming growth factor-beta family. Endocrinology 151(3):1247-1256. https://doi.org/10.1210/ en.2009-0914

Hu X, Xing L, Jiao Y, Xu J, Wang X, Han A, Yu J (2013) BTG2 overexpression increases the radiosensitivity of breast cancer cells in vitro and in vivo. Oncol Res 20(10):457-465

Hummitzsch K, Hatzirodos N, Irving-Rodgers HF, Hartanti MD, Perry VEA, Anderson RA, Rodgers RJ (2019) Morphometric analyses and gene expression related to germ cells, gonadal ridge epithelial-like cells and granulosa cells during development of the bovine fetal ovary. PLoS ONE 14(3):e0214130. https://doi. org/10.1371/journal.pone.0214130

Hyttel P, Fair T, Callesen H, Greve T (1997) Oocyte growth, capacitation and final maturation in cattle. Theriogenology 47(1):23-32. https://doi.org/10.1016/S0093-691X(96)00336-6

Jackowska M, Kempisty B, Antosik P, Bukowska D, Budna J, Lianeri M, Jaśkowski JM et al (2009) The morphology of porcine oocytes is associated with zona pellucida glycoprotein transcript contents. Reprod Biol 9(1):79-85

Kahraman S, Çetinkaya CP, Çetinkaya M, Tüfekçi MA, Ekmekçi CG, Montag M (2018) Is there a correlation between follicle size and gene expression in cumulus cells and is gene expression an indicator of embryo development? Reprod Biol Endocrinol 16(1):69. https://doi.org/10.1186/s12958-018-0388-0

Kempisty B, Jackowska M, Piotrowska H, Antosik P, Woźna M, Bukowska D, Jaśkowski JM et al (2011) Zona pellucida glycoprotein 3 (pZP3) and integrin $\beta 2$ (ITGB2) mRNA and protein expression in porcine oocytes after single and double exposure to brilliant cresyl blue test. Theriogenology 75(8):1525-1535. https ://doi.org/10.1016/j.theriogenology.2010.12.016

Kranc W, Brązert M, Ożegowska K, Budna-Tukan J, Celichowski P, Jankowski M, Kempisty B et al (2018) Response to abiotic and organic substances stimulation belongs to ontologic groups significantly up-regulated in porcine immature oocytes. Med J Cell Biol. https://doi.org/10.2478/acb-2018-0015

Kranc W, Jankowski M, Budna J, Celichowski P, Khozmi R, Bryja A, Borys S, Dyszkiewicz-Konwińska M, Jeseta M, Magas M, Bukowska AP, Brussow KP, Bruska M, Nowicki M, Zabel KB (2018) Amino acids metabolism and degradation is regulated during porcine oviductal epithelial cells (OECs) primary culture in vitro-signaling pathway activation approach. Med J Cell Biol 6:1. https://doi.org/10.2478/acb-2018-0004

Krishna A, Bhatt MLB, Singh V, Singh S, Gangwar PK, Singh US, Mehrotra D et al (2018) Differential expression of c-fos Protooncogene in normal oral mucosa versus squamous cell carcinoma. Asian Pacific J Cancer Prev APJCP 19(3):867-874. https://doi. org/10.22034/APJCP.2018.19.3.867
Ma Y, Andrisse S, Chen Y, Childress S, Xue P, Wang Z, Wu S et al (2017) Androgen receptor in the ovary theca cells plays a critical role in androgen-induced reproductive dysfunction. Endocrinology 158(1):98-108. https://doi.org/10.1210/en.2016-1608

Massari ME, Murre C (2000) Helix-loop-helix proteins: regulators of transcription in eucaryotic organisms. Mol Cell Biol 20(2):429-440

Mauviel A (2005) Transforming growth factor-beta: a key mediator of fibrosis. Methods Mol Med 117:69-80. https://doi.org/10.1385/159259-940-0:069

Nagashima H, Kashiwazaki N, Ashman R, Grupen C, Seamark RF, Nottle M (1994) Recent advances in cryopreservation of porcine embryos. Theriogenology. https://doi.org/10.1016/S0093 -691X(05)80056-1

Nawrocki MJ, Celichowski P, Jankowski M, Kranc W, Bryja A, BorysWójcik S, Kempisty B et al (2018) Ontology groups representing angiogenesis and blood vessels development are highly up-regulated during porcine oviductal epithelial cells long-term real-time proliferation-a primary cell culture approach. Med J Cell Biol 6(4):186-194. https://doi.org/10.2478/acb-2018-0029

Niimura S, Takano H, Onishi A, Hosoe M (2002) Changes in the amount of proteins, glycogen and lipids in porcine oocytes during in vitro meiotic maturation. Anim Sci J 73(5):327-332. https ://doi.org/10.1046/j.1344-3941.2002.00045.x

Niu Y, Wang C, Xiong Q, Yang X, Chi D, Li P, Huang R et al (2015) Distribution and content of lipid droplets and mitochondria in pig parthenogenetically activated embryos after delipation. Theriogenology 83(1):131-138. https://doi.org/10.1016/j.theriogeno logy.2014.09.002

Regassa A, Rings F, Hoelker M, Cinar U, Tholen E, Looft C, Tesfaye D et al (2011) Transcriptome dynamics and molecular cross-talk between bovine oocyte and its companion cumulus cells. BMC Genomics. https://doi.org/10.1186/1471-2164-12-57

Rienzi L, Vajta G, Ubaldi F (2011) Predictive value of oocyte morphology in human IVF: a systematic review of the literature. Hum Reprod Update 17(1):34-45. https://doi.org/10.1093/humupd/ dmq029

Rybska M, Knap S, Jankowski M, Jeseta M, Bukowska D, Antosik P, Jaśkowski JM et al (2018a) Characteristic of factors influencing the proper course of folliculogenesis in mammals. Med J Cell Biol 6(1):33-38. https://doi.org/10.2478/acb-2018-0006

Rybska M, Knap S, Jankowski M, Jeseta M, Bukowska D, Antosik P, Jaśkowski JM et al (2018b) Cytoplasmic and nuclear maturation of oocytes in mammals-living in the shadow of cells developmental capability. Med J Cell Biol 6(1):13-17. https:// doi.org/10.2478/acb-2018-0003

Sarraj MA, Sarraj MA, Chua HK, Sarraj MA, Chua HK, Umbers A, Stenvers KL et al (2007) Differential expression of TGFBR3 (betaglycan) in mouse ovary and testis during gonadogenesis. Growth Factors 25(5):334-345. https://doi.org/10.1080/08977 190701833619

Sathananthan AH (1994) Ultrastructural changes during meiotic maturation in mammalian oocytes: unique aspects of the human oocyte. Microsc Res Tech 27(2):145-164. https://doi.org/10.1002/ jemt. 1070270208

Shuhaibar LC, Egbert JR, Norris RP, Lampe PD, Nikolaev VO, Thunemann M, Jaffe LA et al (2015) Intercellular signaling via cyclic GMP diffusion through gap junctions restarts meiosis in mouse ovarian follicles. Proc Natl Acad Sci USA 112(17):5527-5532. https://doi.org/10.1073/pnas.1423598112

Sicinski P, Donaher JL, Geng Y, Parker SB, Gardner H, Park MY, Weinberg RA et al (1996) Cyclin D2 is an FSH-responsive gene involved in gonadal cell proliferation and oncogenesis. Nature 384(6608):470-474. https://doi.org/10.1038/384470a0

Stefańska K, Chamier-Gliszczyńska A, Jankowski M, Celichowski P, Kulus M, Rojewska M, Zakova J et al (2018) Epithelium 
morphogenesis and oviduct development are regulated by significant increase of expression of genes after long-term in vitro primary culture-a microarray assays. Med J Cell Biol 6(4):195204. https://doi.org/10.2478/acb-2018-0030

Sturmey RG, Leese HJ (2003) Energy metabolism in pig oocytes and early embryos. Reproduction 126(2):197-204. https://doi. org/10.1530/rep.0.1260197

Tan KAL, Turner KJ, Saunders PTK, Verhoeven G, De Gendt K, Atanassova N, Sharpe RM (2005) Androgen regulation of stagedependent cyclin D2 expression in sertoli cells suggests a role in modulating androgen action on spermatogenesis1. Biol Reprod 72(5):1151-1160. https://doi.org/10.1095/biolreprod.104.037689

Topaloglu AK, Reimann F, Guclu M, Yalin AS, Kotan LD, Porter KM, Semple RK et al (2009) TAC3 and TACR3 mutations in familial hypogonadotropic hypogonadism reveal a key role for Neurokinin $B$ in the central control of reproduction. Nat Genet 41(3):354-358. https://doi.org/10.1038/ng.306

Vainio S, Heikkilä M, Kispert A, Chin N, McMahon AP (1999) Female development in mammals is regulated by Wnt-4 signalling. Nature 397(6718):405-409. https://doi.org/10.1038/17068

van Montfoort APA, Geraedts JPM, Dumoulin JCM, Stassen APM, Evers JLH, Ayoubi TAY (2008) Differential gene expression in cumulus cells as a prognostic indicator of embryo viability: a microarray analysis. Mol Hum Reprod 14(3):157-168. https:// doi.org/10.1093/molehr/gam088
Vuong LN, Le AH, Ho VNA, Pham TD, Sanchez F, Romero S, Smitz $\mathrm{J}$ et al (2020) Live births after oocyte in vitro maturation with a prematuration step in women with polycystic ovary syndrome. $\mathbf{J}$ Assist Reprod Genet. https://doi.org/10.1007/s10815-019-01677-6

Wu Y-G, Liu Y, Zhou P, Lan G-C, Han D, Miao D-Q, Tan J-H (2007) Selection of oocytes for in vitro maturation by brilliant cresyl blue staining: a study using the mouse model. Cell Res 17(8):722-731. https://doi.org/10.1038/cr.2007.66

Yoneda A, Suzuki K, Mori T, Ueda J, Watanabe T (2004) Effects of delipidation and oxygen concentration on in vitro development of porcine embryos. J Reprod Dev 50(3):287-295. https://doi. org/10.1262/jrd.50.287

Young J, Bouligand J, Francou B, Raffin-Sanson M-L, Gaillez S, Jeanpierre M, Guiochon-Mantel A et al (2010) TAC3 and TACR3 defects cause hypothalamic congenital hypogonadotropic hypogonadism in humans. J Clin Endocrinol Metabol 95(5):2287-2295. https://doi.org/10.1210/jc.2009-2600

Zhang XY, Chang HM, Taylor EL, Liu RZ, Leung PCK (2018) BMP6 downregulates GDNF expression through SMAD1/5 and ERK1/2 signaling pathways in human granulosa-lutein cells. Endocrinology 159(8):2926-2938. https://doi.org/10.1210/en.2018-00189

Publisher's Note Springer Nature remains neutral with regard to jurisdictional claims in published maps and institutional affiliations. 